\title{
Photoreceptor sensory cilia and ciliopathies: focus on CEP290, RPGR and their interacting proteins
}

\author{
Rivka A Rachel, Tiansen Li and Anand Swaroop*
}

\begin{abstract}
Ciliopathies encompass a broad array of clinical findings associated with genetic defects in biogenesis and/or function of the primary cilium, a ubiquitous organelle involved in the transduction of diverse biological signals. Degeneration or dysfunction of retinal photoreceptors is frequently observed in diverse ciliopathies. The sensory cilium in a photoreceptor elaborates into unique outer segment discs that provide extensive surface area for maximal photon capture and efficient visual transduction. The daily renewal of approximately $10 \%$ of outer segments requires a precise control of ciliary transport. Here, we review the ciliopathies with associated retinal degeneration, describe the distinctive structure of the photoreceptor cilium, and discuss mouse models that allow investigations into molecular mechanisms of cilia biogenesis and defects. We have specifically focused on two ciliary proteins - CEP290 and RPGR - that underlie photoreceptor degeneration and syndromic ciliopathies. Mouse models of CEP290 and RPGR disease, and of their multiple interacting partners, have helped unravel new functional insights into cell type-specific phenotypic defects in distinct ciliary proteins. Elucidation of multifaceted ciliary functions and associated protein complexes will require concerted efforts to assimilate diverse datasets from in vivo and in vitro studies. We therefore discuss a possible framework for investigating genetic networks associated with photoreceptor cilia biogenesis and pathology.
\end{abstract}

Keywords: Ciliopathy, Retinal degeneration, Primary cilium, Sensory cilia, CEP290, RPGR, Bardet-Biedl syndrome, Leber congenital amaurosis, Joubert syndrome, Nephronophthisis

\section{Introduction}

As the field of cilia biology has exploded over the past decade, our understanding has evolved from the initial realization of cilia as important cellular structures to the knowledge that defects in these organelles constitute a unifying framework in numerous syndromic diseases, collectively called ciliopathies. More recently, distinct sets of genes have been identified as causing overlapping symptom clusters, making it possible to link specific genetic mutations to clinical diagnosis. Amidst this rapid progress, confusion arose because disease conditions manifest as a continuum of disorders with varying severity and organ involvement rather than cleanly segregated entities. As a result, even identical gene mutations can give rise to distinct clinical manifestations, while a well-defined clinical syndrome can trace its etiologic origin to a multitude of gene defects. The goal of this review is to focus on the

\footnotetext{
* Correspondence: swaroopa@nei.nih.gov

Neurobiology-Neurodegeneration \& Repair Laboratory, National Eye Institute, National Institutes of Health, Bethesda, MD 20892, USA
}

differences among ciliopathies based on molecular and genetic characteristics and on the realization that assigning a specific clinical diagnosis is only the starting point for identifying the culprit gene. In reaching a clear understanding of molecular mechanisms and future therapeutic strategies, correlating specific symptoms to genetic mutation(s) should provide valuable insights.

We have focused on ciliopathies that include retinal degeneration as part of the clinical spectrum in order to provide a comprehensive analysis of their mutations, phenotypes, subcellular localization of the gene products, and functional insights from respective mouse models. In addition to summarizing the current state of knowledge, we have attempted to define gaps in our understanding of cilia biology and suggested approaches for future investigations.

\section{An overview of ciliogenesis and cilia function}

Cilia can be categorized as primary, sensory or motile. Nearly all cells develop a primary cilium, which serves 
either as a precursor to a cluster of motile cilia (in cells such as ventricular ependyma and tracheal epithelium) $[1,2]$ or remains as an environmental sensor. Given that most primary cilia are now known to enable cells to interact with and respond to their environment [3], the distinction between primary and sensory cilia has lost much of its meaning. These cilia are highly specialized organelles that have developed to mediate perception of light, sound, odorants, osmolarity, pressure, flow, circulating hormones, and position within the plane of a tissue (via gradients of morphogens); these perceptions are then transmitted into the cell via signaling pathways to mediate distinct responses. For example, photoreceptor outer segments are filled with stacks of membranous discs densely packed with rhodopsin, the receptor molecule that initiates a transduction cascade turning photons into electrical signals. In the cochlea, the kinocilium serves as a transient anchor point for positioning the stereocilia bundles. In olfactory epithelium, the multiple cilia in each cell converge odorant receptors in the membrane and orchestrate G-protein coupled receptor signaling in response to environmental stimuli. Many recent reviews have summarized ciliogenesis and signaling pathways in cilia [4-13], motile cilia [14], mechanosensory cilia mechanics [15], cilia as stress and flow sensors [16], and clinical manifestations and diagnosis of neuronal pathology $[17,18]$.

\section{Ciliopathies and associated pleiotropic phenotypes}

Kartagener's syndrome was one of the earliest descriptions of a motile cilia disorder [19]. While Bardet-Biedl syndrome (BBS) was recognized as a distinct collection of phenotypes at least 60 years ago [20] and Joubert syndrome (JBTS) as early as 1968 [21], ciliopathies have become recognized to have sensory cilia as a unifying theme only during the last decade [22,23]. Clinical entities that affect motile cilia only, such as Kartagener's syndrome/primary ciliary dyskinesia, manifest situs inversus, bronchiectasis and sinus/respiratory complications, but lack other clinical features commonly seen in ciliopathies. The etiology of primary ciliary dyskinesia lies in genetic defects that inactivate selected molecular motors or structures within the cilia critical for motility, usually in dyneins or radial spoke components [24], thereby explaining more uniform and limited manifestations. Interestingly, defects in the sensory ciliopathies encompass a broader spectrum of gene functions including cilia biogenesis and structure, receptor trafficking and signaling, implying that sensory roles of cilia are more complex and critical to life.

Ciliopathies share an overlapping conglomeration of features, exhibiting retinal degeneration, cognitive impairments, cerebellar dysmorphogenesis, kidney cysts, hepatic fibrosis, polydactyly, situs inversus, obesity, skeletal/ thoracic dysmorphology, genitourinary defects, cardiorespiratory abnormalities, neural tube patterning defects, and/or hydrocephalus (Figure 1) [25-27]. Although various syndromes may have unique symptom clusters, the distinction among clinical entities is often blurred. Clinical diagnosis alone thus provides little insight into disease etiology. Adding molecular diagnosis to classical clinical findings can be valuable in clarifying possible pathogenic mechanism(s). For example, the distinction between nephronophthisis (NPHP) and Senior-Løken syndrome (SLSN) depends on the presence of retinal findings in SLSN; however, individuals in NPHP pedigrees can also manifest ocular defects [28]. Similarly, the distinction between $\mathrm{COACH}$ syndrome (Joubert syndrome with congenital hepatic fibrosis) and JBTS is blurry. With a goal to establish a link between clinical features, syndromes, and genetic causes, we have summarized relevant details of many ciliopathies and their causative genes based on information from the Online Mendelian Inheritance in Man database in Figure 1.

In contrast to motile cilia, sensory cilia are uniquely modified to carry out a particular function in a specific organ. As each tissue is designed to mediate a different sensory function, the associated pathways are more complex and slow to unravel (see Table 1). To comprehend the significance of cilia involvement, it would be helpful to delineate the pathological process in each tissue; for example, kidneys may have either massive polycystic disease or glomerulonephritis, differing pathologies that probably represent distinct etiologies. Cellular pathology and dysfunction in sensory ciliopathies may result from absent, shortened or otherwise morphologically abnormal cilia; from normal cilia structure but no transport/ function; or from different cell types/tissues affected in various conditions. In photoreceptors, for example, mutations in various ciliopathy genes result in a number of distinct phenotypes, ranging from complete failure of connecting cilium formation [29] and curtailed outer segment biogenesis [30], to abnormalities of disc assembly [31]. All of these defects should eventually be traceable to a stage in ciliogenesis, transport or maintenance. Photoreceptors thus offer a unique opportunity to evaluate the contribution of ciliary proteins.

\section{Photoreceptor structure, modified cilium and transport}

The dense stacks of rhodopsin-laden discs in photoreceptor outer segments represent a highly complex and unique example of sensory cilia specialization, enlarged to house the machinery of phototransduction. As the vast majority of photoreceptors in mouse and human retina are rods, our remarks are directed primarily towards rod photoreceptors. Four ciliary compartments can be defined in photoreceptors, based on expression and other studies (Figure 2 and legend); these include the distal cilium (operationally defined as the domain occupied by Rp1 and Mak), the proximal cilium or transition zone (known 


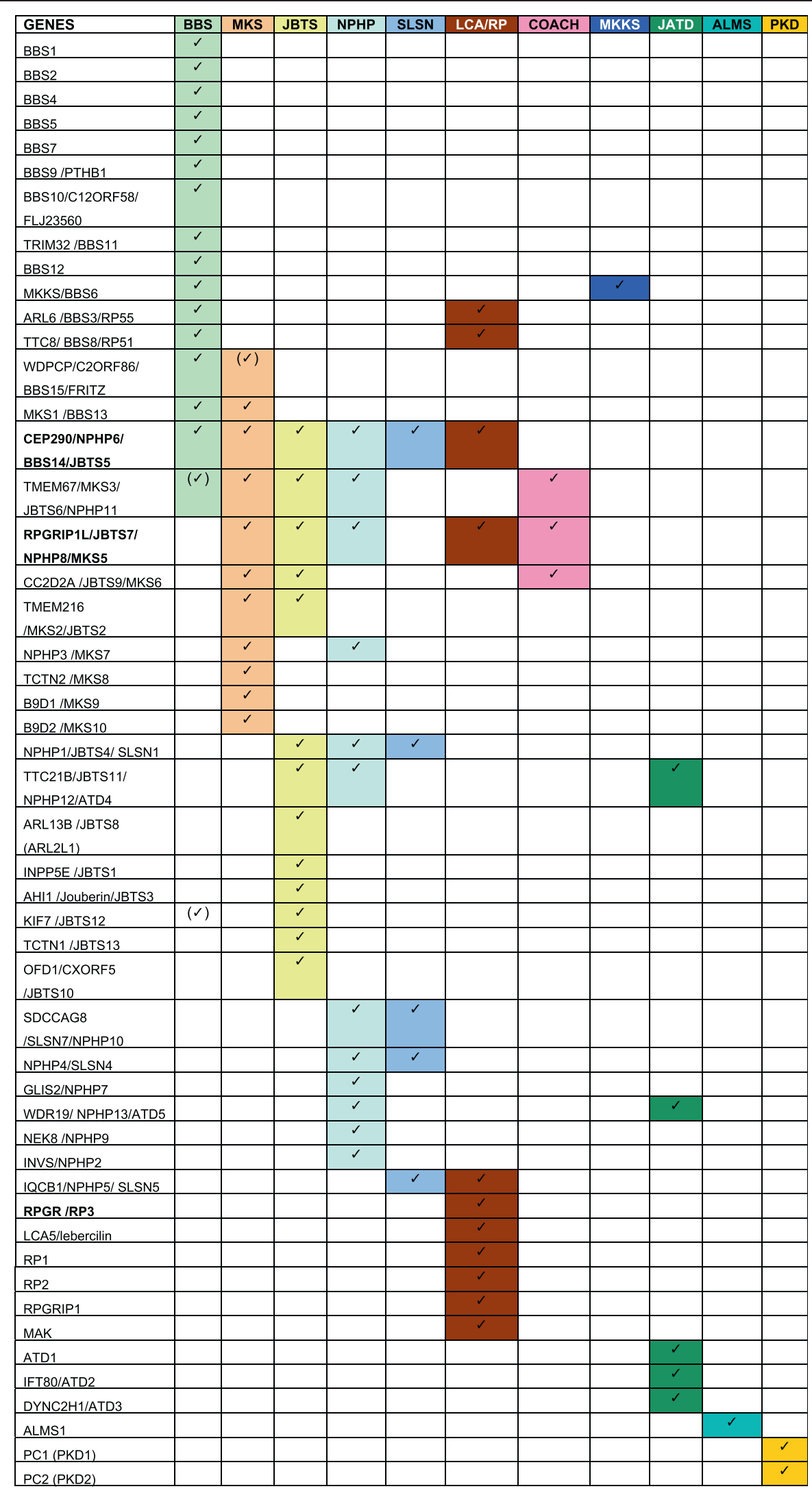

Figure 1 (See legend on next page.) 
(See figure on previous page.)

Figure 1 Ciliopathy genes with syndromic manifestations. Information from Online Mendelian Inheritance in Man (http://www.ncbi.nlm.nih. gov/omim). ALMS, Alstrom syndrome; BBS, Bardet-Biedl syndrome; COACH, Joubert syndrome with congenital hepatic fibrosis; JATD, Jeune asphyxiating thoracic dystrophy; JBTS, Joubert syndrome; LCA/RP, Leber congenital amaurosis/retinitis pigmentosa; MKKS, McKusick-Kaufman syndrome; MKS, Meckel-Gruber syndrome; NPHP, nephronophthisis; PKD, polycystic kidney disease; SLSN, Senior-Lø1ken syndrome.

in photoreceptors as the connecting cilium), the basal body, and the periciliary ridge complex or periciliary membrane complex $[75,76]$, which is analogous to what is referred to as the ciliary pocket in general cilia literature [77]. Expression of ciliopathy-associated proteins is generally restricted to one of these four domains (Figure 2). Thus, it is now possible to divide ciliopathy proteins by discrete anatomical localization and to contemplate understanding molecular mechanisms based on precise expression data from confocal images. These proteins are identified as being expressed in specific compartments. Axo: INV/NPHP2 [43], NPHP3 [43], NPHP9/NEK8 [43], RP1, SDCCAG8 [78], MAK [79]; TZ/CC: NPHP1 [43], NPHP4 [43], NPHP8/RPGRIP1L [43], NPHP5/ IQCB1 [43], NPHP6/CEP290 [43], RPGR RPGRIP1 [80-82], AHI1 [83], RP2 [84], Lebercilin [85], IFT88 [85]; BB: BBS1, BBS2, BBS3, BBS4, BBS5, BBS7, BBS9, MKKS/BBS6 [31]; PC/PCC: USH2A/usherin [75], DFNB31/USH2D/ whirlin, [75], VLGR1 [75]. Having immuno-electron micrograph images of protein expression in relationship to microtubule bundles, basal body, and transition zone will further advance our understanding of protein function.

Compartment 1 , the distal cilium or axoneme, contains proteins that primarily modulate cilium length; these include MAK [79], RP1 [87], RP1L1 and IFT20 [88]. In photoreceptors, compartment 1 delineates the base of the outer segment (Figure 2B,E). Compartment 2 is referred to as the connecting cilium in photoreceptors and is equivalent to the transition zone of motile and primary cilia. Proteins in this zone include CEP290 [30,89-91], RPGR [30,92-99], RPGRIP1 [80], RPGRIP1L [100-105], IFT88 [106-108], KIF3A [109], KIF7 [110], and LCA5/ Lebercilin [85]. Although intraflagellar transport proteins mediate ciliary transport along the length of the cilium, antibody localization via immunohistochemistry identifies them in specific compartments. We believe that the appearance of being concentrated in a particular subzone may reflect a bottleneck in transit. Compartment 3 comprises the basal bodies and the pericentriolar material. The proteins in this domain include BBS1 [111], BBS4 [111], BBS3 [112], MKKS [113], TTC8/BBS8 [114], and RAB8A [115]. In addition to these three core compartments, a peripheral component contributing to ciliopathies is the periciliary ridge (Compartment 4). The analogous structure in non-photoreceptor cells is the ciliary pocket [77]. The periciliary ridge was originally described in frog photoreceptors by scanning electron microscopy [76]. The same structure is not visible in mammalian photoreceptors; however, three USH2 proteins (usherin, whirlin and VLGR1) mark a functionally equivalent region, referred to as the periciliary membrane complex, to indicate a highly specialized membrane microdomain [75,116]. Distal to the basal body are structures called rootlets, which provide support for the basal bodies and cilia. A notable

Table 1 Molecular pathways associated with ciliary pathology in each affected tissue

\begin{tabular}{lll}
\hline Organ/tissue/cell type & Signaling/biogenesis pathway(s)Wnt, Shh, PDGF, PCP & $\begin{array}{l}\text { Reviews and other } \\
\text { references }\end{array}$ \\
\hline Retina - photoreceptors & Ciliogenesis and transport & {$[32,33][34]$} \\
Cognition - brain & GPCR trafficking to neuron cilia & {$[35,36]$ JBTS: [37] [38,39] } \\
Cerebellum - granule cells? & IFT, Wnt, Shh & {$[40-42]$} \\
Kidney cysts & Wnt/PCP, Shh, mTOR, Ca ${ }^{2+}$; mechanosensation, fluid pressure, proliferation & {$[43-50]$} \\
Hepatic fibrosis ${ }^{\text {a }}$ & Ductal plate malformation - PCP?; receptors expressed on cilia; cysts - & {$[51-57][46]$} \\
& hyperproliferation & {$[58]$} \\
Polydactyly & Shh & {$[59]$} \\
Situs inversus & Nodal, PCP & {$[60][46]$} \\
Obesity & Neuronal cilia receptors Shh & {$[58,61-66]$} \\
Skeletal/thoracic & Mechanical sensation, Shh, IFT & {$[67]$} \\
Genitourinary & Ca ${ }^{2+}$ & {$[1,68][69][70][71]$} \\
Cardiorespiratory & Heart - Shh, cardiogenesis; lung - primary cilia precede motile cilia & {$[72][73,74]$} \\
Neural tube defects/ & Shh, PCP & \\
hydrocephalus & &
\end{tabular}




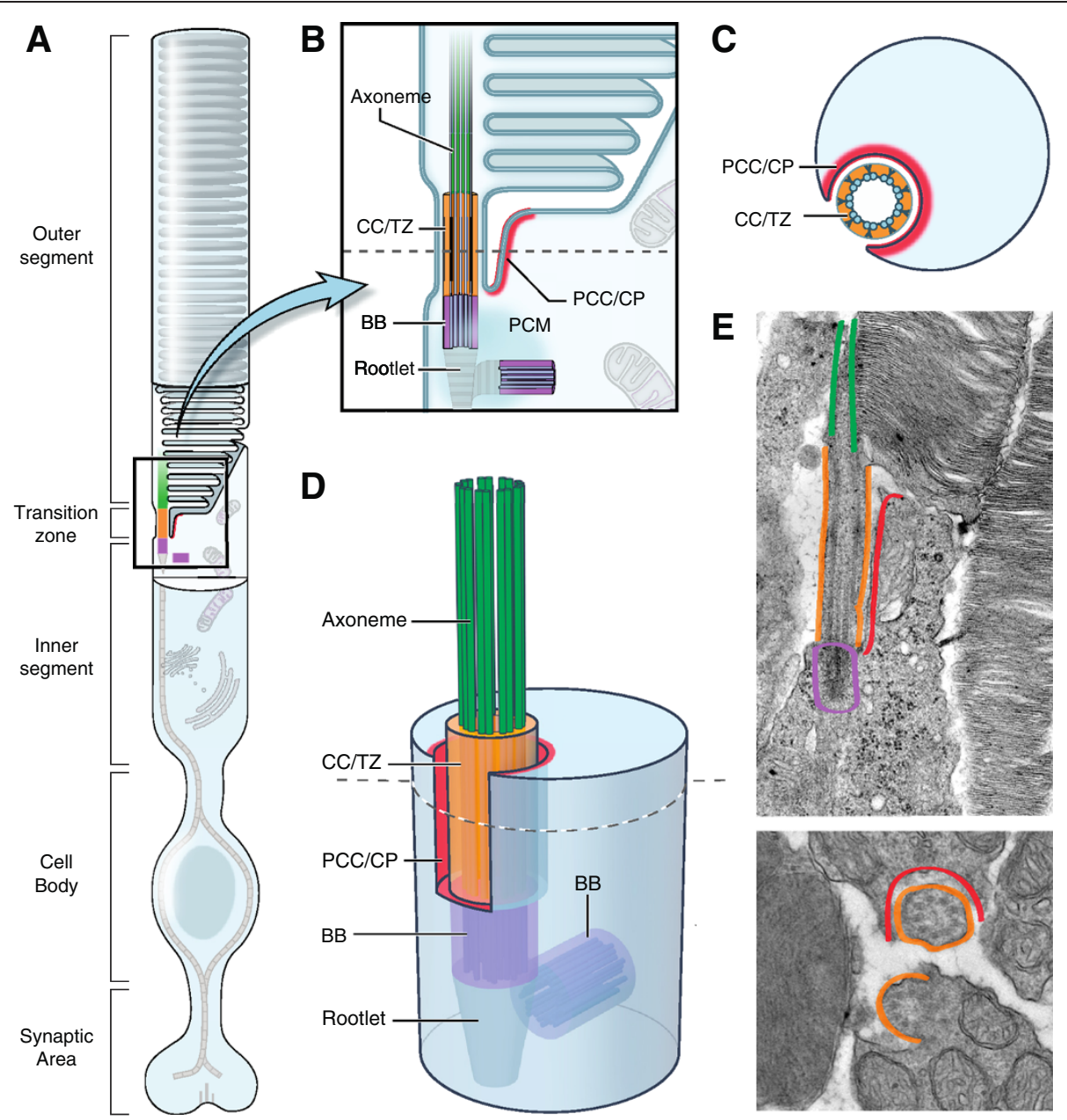

Figure 2 Four distinct compartments in photoreceptor primary cilia, indicating known proteins that define their respective extent. The four compartments are: (1) distal cilium or axoneme (Axo; green); (2) connecting cilium/transition zone (CC/TZ; orange); (3) basal body (BB; purple); and (4) periciliary complex or ciliary pocket (PCC/CP; red). These compartments serve discrete functions in the cilium. (A) Schematic of a photoreceptor, showing specialized domains of the cell. The primary cilium elaborates into stacks of outer segment disks packed with rhodopsin, which serves as the primary light sensors of the cell. (B) Enlargement of the photoreceptor transition zone in two dimensions showing the four structural and functional domains in which most ciliary proteins are expressed. These domains are identified by known protein markers, such as acetylated a-tubulin (Axo + CC/TZ) and $\gamma$-tubulin (BB). Note: illustration of outer segment is based on a traditional model of disc morphogenesis in which nascent discs are open to the extracellular milieu, but a newer model posits that new discs form within the enclosure of outer segment plasma membrane [86]. (C) Cross-section through the CC/TZ of the photoreceptor showing the relationship between the microtubules of the cilium and the inner segment, via the PCC/CP. (D) Three-dimensional representation of the transition zone and adjacent domains shown in (B). Note the manner in which the PCC surrounds the TZ. Note also that the TZ is the one compartment that contacts all other compartments. (E) Electron micrographs showing longitudinal (top) and cross-section (bottom) views of mouse photoreceptors. Functional domains are highlighted with the corresponding colors shown in the other panels.

protein in this compartment is CROCC (rootletin) [117]. While several not strictly ciliary proteins have been included in the list of ciliopathy proteins (Figure 1) as mutations in these cause cilia-related phenotypes, a number of cilia proteins are not included - for example, trafficked cargos that are integral for outer segment function or cytoskeletal proteins that are general features of all ciliated cells.

Knowing the compartmental localization of individual proteins within the cilium will lead to new insights into cilia biogenesis and function. For example, groups of cilia proteins expressed in the same compartment, such as CEP290 and RPGR, may function in related pathways (Figure 3). Other documented interactions between proteins expressed in adjacent compartments (CEP290 and MKKS [31]; NPHP1 and NPHP4 [43]; RPGR and USH2 [118]) might provide clues to how proteins in different compartments cooperate in mediating transport or signaling. Interesting and non-exclusive possibilities are: the expression patterns indicate pools of protein accumulation 


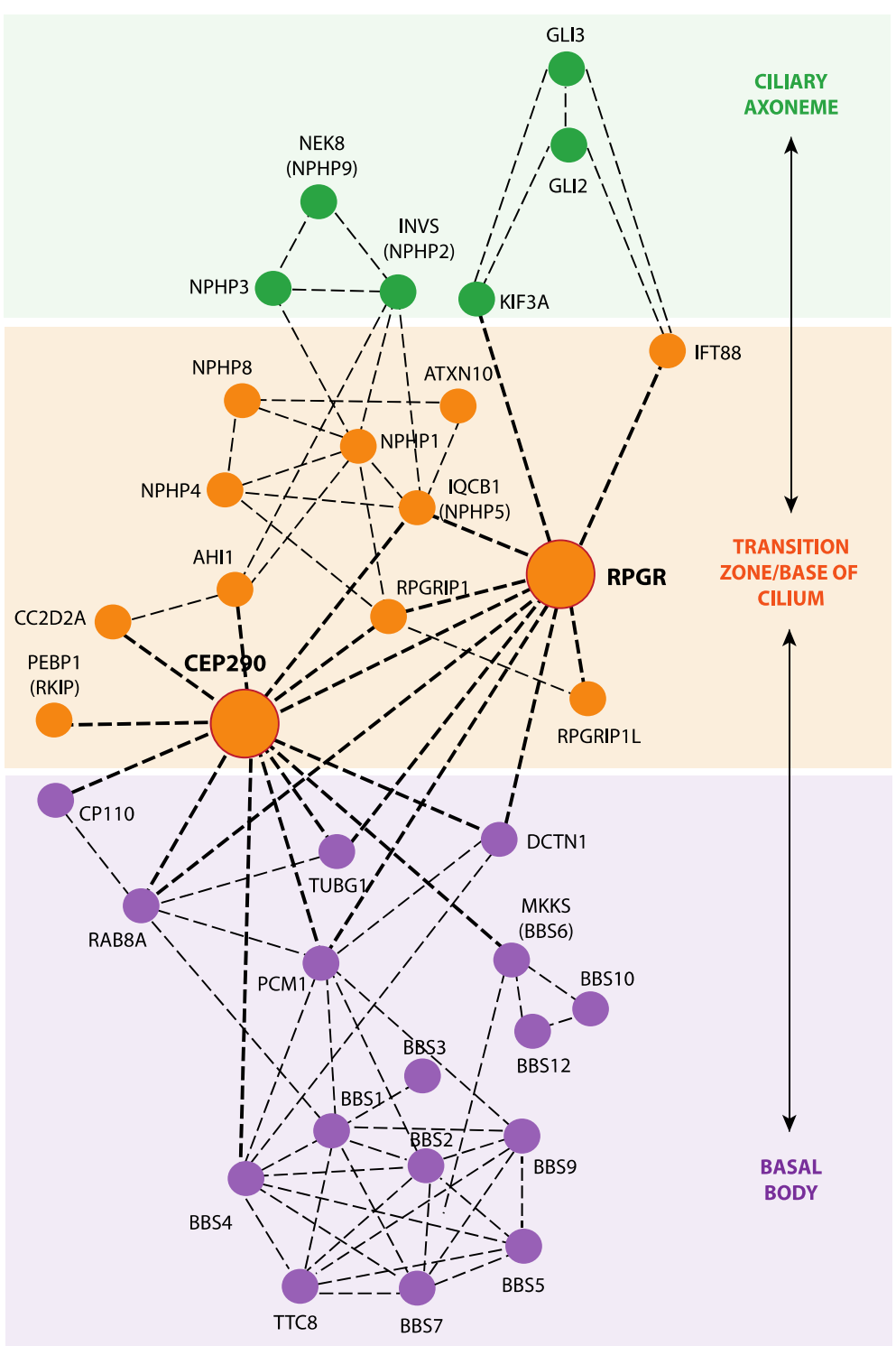

Figure 3 Interactome of ciliary proteins directly or indirectly connected to CEP290 and RPGR. Ciliary proteins directly (bold dotted lines) or indirectly (thin dotted lines) connected to CEP290 and RPGR. Ciliary expression domains are colored as in Figure 2. This network shows representative interactions.

rather than absolute boundaries; a system of protein relays transports cargo or signaling from the cell body to the cilia and back; interacting proteins are part of larger multiprotein complexes with overlapping boundaries; and/or discrete molecules of a given protein (for example, CEP290) form complexes within its primary compartment (transition zone), while other CEP290 domains interact with separate complexes in other compartments (for example, basal body). Given the predicted three-dimensional structure of CEP290 as a long, fibrillar coiled-coil protein, and the plethora of its interactors (Figure 3), a central role in transport and communication is suspected.

\section{Retinal degeneration in clinical ciliopathies}

Loss or dysfunction of photoreceptors is a moderately penetrant phenotype in ciliopathies. In the clinic, the retinal defect is called retinitis pigmentosa (RP), and in cases with an early childhood onset clinicians frequently give the diagnosis of Leber congenital amaurosis (LCA). Differences among ciliopathy phenotypes reflect both the causative gene and specific mutations within each gene. Retinal degeneration in BBS $[25,119]$ tends to be slower compared with other ciliopathies. Patients with MeckelGruber syndrome have severe neural tube closure defects and early lethality; vision is thus not generally assessed in 
these patients [120,121]. Many JBTS patients develop a degree of childhood vision impairment [101,110,120]. Alstrom syndrome patients develop vision loss in young adulthood [122]. Like JBTS cases, patients with SLSN tend to exhibit early vision loss [34,123-125]. Visual impairment in a child can be the presenting feature of Jeune syndrome (Jeune asphyxiating thoracic dystrophy) [126].

\section{Mouse models of human ciliopathies with retinal degeneration}

Integration of biochemical, cell biologic, protein interactions and human genetic/clinical datasets with genetic mutations in mice provides deeper insight into each gene function as it relates to cilia and pathogenic processes. Animal studies can also explain the pleiotropic nature of ciliopathies and apparent variability in clinical and disease manifestations; these may include spatial/ temporal expression pattern differences, functional redundancies and variations in genetic background. Moreover, cell-based and gene-based therapies can be evaluated for toxicity and therapeutic value before moving to larger animal (dog, primate) and human studies. A large number of ciliopathy mouse models with retinal degeneration have been reported and are summarized in Table 2. Here, we focus on two ciliopathy genes involved in retinal dystrophy: CEP290, mutations in which cause up to 15 to $25 \%$ of LCA [127]; and RPGR, the most common cause of X-linked RP and one of the most frequent causes of all forms of RP [128,129].

CEP290 mutations lead to a range of ciliopathy syndromes with variable clinical manifestations in humans [121,166-168] (Figure 1). Many patients present with fullspectrum ciliopathy yet select alleles cause only rapid photoreceptor degeneration (LCA) $[89,127,169]$. A hypomorphic allele of Cep290, rd16, has been described in mice [30]; Cep290 ${ }^{\text {rd16/rd16 }}$ mice show rapid degeneration of rod photoreceptors beginning around postnatal day 14 and leaving only residual cones by postnatal day 28 [89]. Slower cone loss and preservation of central pathways in Cep290 rd16 mice provide opportunities for therapy [137]. Aside from the vision loss, the Cep290 ${ }^{\text {rd16/rd16 }}$ mice reveal defective olfactory transport of $\mathrm{G}$ proteins leading to anosmia [90] and deafness caused by cochlear hair cell dysfunction [31]. A possible mechanism of photoreceptor cell death in Cep290 ${ }^{\text {rd16 }}$ mice may involve abnormal accumulation of RKIP, the Raf-1 kinase inhibitor, which inhibits cilia formation [91]. Examination of the retinal phenotype of Rkip-knockout mice should shed further light on this question [170]. The Cep $290^{\text {rd16 }}$ allele is probably hypomorphic, given the expression of the protein with an inframe deletion and a milder phenotype. Based on the human data, a null allele of Cep290 is expected to have a severe, full-spectrum ciliopathy phenotype, which has recently been confirmed in mice (Rachel RA, Yamamoto EA, Dong L, Swaroop A, unpublished data).

In contrast to CEP290, RPGR mutations primarily cause retinal degeneration (with a few leading to syndromic phenotypes) [171-173]. The RPGR gene produces multiple alternatively spliced transcripts [174-176], all of which encode an N-terminal RCC1-like domain that is structurally similar to the RCC1 protein [177]. One major constitutive isoform spans exons 1 through 19 (RPGR ${ }^{\text {ex1-19) }}$ and carries a C-terminal isoprenylation site [178]. The other major variant contains exons 1 to 14 and terminates with a large, alternative ORF15 exon ( $R P G R^{\text {orf } 15}$ ) [128]. The RPGR-ORF15 isoform is expressed predominantly in photoreceptors [92] with some exceptions [179], concentrated in the connecting cilia [95], and appears to be the functionally important in the retina as all diseasecausing mutations are present in this variant $[129,172,180]$. Conventional gene targeting that disrupted the RCC1-like domain abolished the expression of both types of variants in Rpgr-knockout mice [95]; however, unlike human patients, the retinal degeneration in this mutant is slow despite defective localization of opsins to photoreceptor outer segments. An abbreviated form of Rpgr-orf15 transgene seems to reverse the disease phenotype in this line [94]. A naturally occurring mutant mouse ( $r d 9)$ was shown to affect only the orf15 exon of the Rpgr gene [149], mimicking a majority of human patients. The retinal degeneration in the $r d 9$ mutation is also somewhat slow. Interestingly, a recently reported mouse conditional knockout (cko) mutant exhibited relatively earlier onset of retinal disease compared to Rpgr-ko and rd9 [150]. The phenotypes in these mouse mutants are closer to what is expected in patients with $R P G R^{\text {orf15 }}$ mutations $[150,172,180]$.

Mouse models have been generated for RPGR and CEP290 interactors and related ciliary proteins such as RPGRIP1, NPHP and BBS proteins (Figure 3). Retinal degeneration has been demonstrated in all of these models (Table 2). The retina in these mice reveal ultrastructural defects and provide insights into how cilia proteins contribute to ciliogenesis, the sequence of events in ciliogenesis, and functional interactions among specific proteins. Moreover, we can evaluate the effects of an individual allele on a uniform genetic background in mice. Such a feature allows the engineering of triple and quadruple mutants on a less variable genetic background to enable examination of the contribution of each allele to the phenotype [31,181]. Unexpectedly, such studies have begun to reveal surprising results. Rather than combinations of ciliopathy alleles necessarily resulting in a more severe phenotype, genetic findings reveal more complex relationships among different ciliary proteins. For example, loss of Dync2h1, involved in retrograde cilia trafficking, disrupts Sonic hedgehog signaling and cilia formation, yet combining this mutation with heterozygous loss of Ift172, an 
Table 2 Mouse models of ciliopathies with retinal degeneration ${ }^{\text {a }}$

\begin{tabular}{|c|c|c|c|c|}
\hline Gene symbol & $\begin{array}{l}\text { References for } \\
\text { mouse model }\end{array}$ & Retinal phenotype & Interactors $^{\mathrm{b}}$ & $\begin{array}{l}\text { PR domain } \\
\text { expressed }\end{array}$ \\
\hline MAK & [79] & $60 \%$ ONL left at 1 month, 30\% at 6 months & & Axoneme \\
\hline KIF3A & {$[130,131]$} & Intermediate rate of degeneration; $20 \%$ of wild-type ONL thickness by 10 to 12 weeks & $\begin{array}{l}\text { DISC1, MAP3K11, PLEKHA5, USP7, } \\
\text { PPP1R15A, RPGR }\end{array}$ & Axoneme \\
\hline RP1 & [132-136] & Slow retinal degeneration; $\sim 40 \%$ left at 6 months & APC, MAPRE2, MAPRE3, NIF3L1, POLE & Axoneme \\
\hline CEP290 & {$[30,89,137]$} & Rapid retinal degeneration; ciliogenesis defects depending on strain & $\begin{array}{l}\text { RPGR, IFT88, PCM1, DCTN1, BBS4, } \\
\text { MAPK10, GNG13 }\end{array}$ & $\mathrm{CC} / \mathrm{TZ}$ \\
\hline AHI1/Jouberin & {$[83,138,139]$} & Rapid - starting to go by P12; only 2 to 3 ONL rows by P24. Very few if any OS/IS & SMYD2 & $\mathrm{CC} / \mathrm{TZ}$ \\
\hline TMEM67/MKS3 & {$[140]$} & Early and rapid retinal degeneration & MKS1 & $\mathrm{CC} / \mathrm{TZ}$ \\
\hline $\begin{array}{l}\text { IFT88/TTC10 } \\
\text { Tg737 }\end{array}$ & {$[106,141]$} & Similar to Cep290 $0^{\text {d } 16}$ - failure of outer segments to elongate & RPGR, PRRC2A, SMNDC1, PAN3, SLC9A8 & $\mathrm{CC} / \mathrm{TZ}$ \\
\hline KIF7 & {$[110,142]$} & Retina not examined; mice die perinatally & USP22 & $\mathrm{CC} / \mathrm{TZ}$ \\
\hline LCA5 lebercilin & [85] & $\begin{array}{l}\text { Rapid degeneration; between P12 and P28, reduced to } 2 \text { to } 3 \text { ONL rows. CC develops but } \\
\text { little if any OS material. }\end{array}$ & GRIN2B, OFD1/JBTS10, IFTS & $\mathrm{CC} / \mathrm{TZ}$ \\
\hline RP2 & {$[84,143-145]$} & Only information on function of the protein in transport within cells & UNC119, ARL3, YWHAB, APLP2 & $\mathrm{CC} / \mathrm{TZ}$ \\
\hline RPGRIP1 & {$[146,147]$} & Only three rows of ONL nuclei by 3 months of age. Overproduction of outer segments & RPGR, NPHP4, TFE3, SRPX, CEBPA & $\mathrm{CC} / \mathrm{TZ}$ \\
\hline TCTN1 & {$[148]$} & Retina not examined; mice die prenatally & $\begin{array}{l}\text { MKS1, TMEM216, TMEM67, CEP290, B9D1, } \\
\text { TCTN2 AND CC2D2A. }\end{array}$ & $\mathrm{CC} / \mathrm{TZ}$ \\
\hline RPGR & {$[93,95,149,150]$} & Slow retinal degeneration & CEP290, RPGRIP1, IFT88, KIF3A, RAB8A & $\mathrm{CC} / \mathrm{TZ}, \mathrm{BB}$ \\
\hline ALMS1 & {$[151-154]$} & $\begin{array}{l}\text { Slow degeneration - slight reduction in ONL thickness at } 24 \text { weeks; loss of OS over time; still } \\
\text { some left at } 24 \text { weeks by rhodopsin staining }\end{array}$ & $\begin{array}{l}\text { MEGF1, OFD1, TUBGCP2, TUBGCP3, } \\
\text { TUBGCP4, CEP290(MS) }\end{array}$ & BB \\
\hline ARL6/BBS3 & {$[155]$} & Medium-slow retinal degeneration; hydrocephalus & BBS1, ARL6IP1, ARL6IP5, ARL6IP4, ARL6IP6 & BB \\
\hline BBS1 & {$[87,156]$} & Slow degeneration ( 3 to 4 rows of ONL nuclei at 6 months); CC present but disrupted OS & BBS9, EEF1A1, ALDOB, ARL6/BBS3, PCM1 & BB \\
\hline BBS2 & {$[157,158]$} & $\begin{array}{l}\text { Slow degeneration - half ONL at } 5 \text { months; almost no ONL nuclei by } 10 \text { months. OS have } \\
\text { typical indistinct, wavy pattern }\end{array}$ & EEF1A1, ALDOB, BBS7, BBS9 & BB \\
\hline BBS4 & {$[156,159-161]$} & $\begin{array}{l}\text { Intermediate rate of retinal degeneration; } 2 / 3 \text { of ONL remaining at } 6 \text { weeks; all PR lost by an } \\
\text { unspecified adult age }\end{array}$ & PCM1, ALDOB, DCTN1, EEF1A1, EPAS1 & BB \\
\hline TTC8/BBS8 & [162] & Slow degeneration - ONL half-thickness in the 'adult'. OS maybe longer than wild-type & BBS9, PCM1, BBS4, BBS1, BBS2 & BB \\
\hline MKKS/BBS6 & {$[74,163]$} & Medium-slow degeneration; bulging, disorganized OS & CEP290, PTN, STK16, TGIF1, ICA1 & $\begin{array}{l}\text { BB and } \\
\text { proximal rootlet }\end{array}$ \\
\hline RAB8A & {$[164]$} & Retinal phenotype has not been examined or published & RPGR, RABIF, BAG6, OCRL, RAB10, PQBP1 & BB \\
\hline TRIM32/BBS11 & {$[165]$} & Retinal phenotype has not been examined or published & ATXN1, UBE2N, SFN, UBQLN4, UBE2V1 & N/A \\
\hline
\end{tabular}

$\mathrm{BB}$, basal body; CC/TZ, connecting cilium/transition zone; ONL, outer nuclear layer; OS/IS, outer segments/inner segments; $\mathrm{P}$, postnatal day; PR, photoreceptors. ${ }^{\mathrm{S}} \mathrm{Selection}$ criteria for inclusion in Table 2: ciliopathyrelated (even if no human disease has yet been described); and interaction with Rpgr or Cep290; and/or associated with retinal degeneration.

${ }^{\mathrm{b}}$ Data in this column are taken primarily from entries in genecards.org. Genes in bold are CEP290 and/or RPGR interactors. 
anterograde motor, results in a milder phenotype. A priori this would suggest that neutralizing two opposite forces restores equilibrium; however, reduction of the Ift122 retrograde motor also represses the Dync $2 h 1$ phenotype [181]. Another indication of complexity in the biogenesis and function of cilia comes from the interaction of Cep290 and Mkks, a $B B S$ chaperonin protein. In this scenario, loss of Mkks ameliorates the sensory cilia defects in Cep290 2 d16 mutant mice, and vice versa [31]. Together these findings suggest a dynamic and delicate equilibrium among opposing forces in cilia function.

Mouse models with long-term photoreceptor survival and intermediate rates of disease progression should provide optimal opportunities for designing and evaluating therapies. Those with extremely rapid degeneration may not allow sufficient time for gene-based or cell-based therapy to show benefit (see, however, results on Aipl1 $^{k o / k o}$ [29]), whereas those with very slow degeneration are impractical because of the required time and resource commitment. The Rpgr-cko and $\mathrm{Nr}{ }^{k o / k o} / \mathrm{Cep} 290^{r d 16 / r d 16}$ double mutants display appropriate characteristics for designing treatments of retinal disease caused by $R P G R$ and CEP290 mutations. $\mathrm{Nr}^{\mathrm{ko} / \mathrm{ko}} / \mathrm{Cep} 290^{\mathrm{rd16} / \mathrm{rd16}}$ mice have the Cep290 ${ }^{\text {rd16 }}$ mutation on the background of an allcone photoreceptor retina due to the loss of $\mathrm{Nrl}$; in this model, the cones survive longer than rapidly degenerating rods, allowing a longer window for treatment [89]. The Rpgr-cko model displays retinal degeneration that begins during the first months of life, allowing time for treatment options to be tested and evaluated [150].

For most ciliopathies, mouse models fail to completely recapitulate the human phenotype. For example, mouse Rpgr mutants exhibit a milder phenotype. At least nine genes have been identified as underlying Usher syndrome; yet most mouse mutants (except whirlin and usherin that cause type II Usher syndrome) bearing one of these mutations develop hearing deficits but not visual dysfunction [182]. In addition, many BBS mouse models do not, in general, develop polydactyly, unlike their human counterparts.

\section{Sources of complexity in ciliopathy classification}

Confusion in the nomenclature of ciliopathies originates from pleiotropy of phenotypes and from variations introduced at multiple levels, including transcriptional/ translational regulation, protein-protein interactions, and cellular function. Tissue-specific expression of different splice variants or protein isoforms and their subcellular localization contribute to this complexity (see Figure 2), as in the case of RPGR $[99,183]$. If a gene is required for cilia formation or function in all tissues, one would expect a full-spectrum ciliopathy or prenatal lethality. However, functional redundancy and tissue/cell type selectivity (for example, of $R P G R^{\text {orf } 15}$ transcript primarily in photore- ceptors) would result in a more restricted phenotypic spectrum that is also susceptible to modifier effects. In the sense that a complete disruption of ciliogenesis is incompatible with life, many ciliopathy genes would appear to be only partially required for ciliogenesis or function. Different alleles of the same gene (null vs. hypomorph vs. dominant negative) might exhibit varying severity because of the specific functional modules that are impacted $[168,169,184]$. Functional redundancy in genes causing a specific syndrome and phenotypic overlap among syndromes contribute greatly to complexity (Figure 1 and Table 2) [185]. Modifier genetic variants that do not cause disease on their own could modulate phenotypic spectrum of a disease-causing allele in a genetically diverse (outbred) population (such as humans) by combining alleles of different genes $[103,138,169,186]$. This phenomenon seems to occur in particular with BBS [187-190].

Basing diagnosis on a combination of molecular definition and clinical symptoms can help as it would clear up some of the confusion resulting from diagnosis based strictly on phenotypic manifestations. Some ciliopathies are caused by mutations in genes that are primarily associated with non-ciliopathy syndromes (for example, TRIM32/ BBS11, NPHP3, and KIF7). These genes are specifically associated with pathology in certain organs; for example, NPHP3 is associated with renal-hepatic-pancreatic dysplasia, BBS11/TRIM32 causes limb girdle muscular dystrophy, and KIF7 causes acrocallosal syndrome - none of these is considered a ciliopathy. Additionally, different signaling pathways and mechanisms may operate in distinct tissues. Exceptions also exist to the rule of motile cilia having a $9+2$ microtubule configuration and sensory cilia having a $9+0$ structure [191]. Identifying these various sources and levels of complexity are essential. NPHP and SLSN both have kidney disease, but SLSN includes retinal degeneration; however, some patients with NPHP also have retinal disease. Mutations in only two proteins causing NPHP are so far known to also cause SLSN - that is, only mutations in those two proteins, SDCCAG8 and NPHP4, can cause RP/LCA symptoms in addition to isolated renal pathology (Figure 1). Examining whether these two proteins have retina-specific isoforms would be of interest.

\section{Perspectives and future directions}

In this review we have discussed differences between human ciliopathies and their respective mouse models, focusing on CEP290, RPGR and their interactors. We have highlighted the importance of distinct compartments within cilia showing unique patterns of protein expression and their frequent interactions with proteins in the same or adjacent compartments. Given the complexity of these interactions, precise localization and function of each protein should provide valuable insights and testable 
hypotheses related to disease mechanisms. We believe that uniform analysis of tissue expression patterns is critical for elucidating the role for each gene in the retina and other relevant cell types. Expression of each isoform should be determined relative to a distinct ciliary compartment. At this stage, it is unclear for most cilia proteins whether a specific isoform is expressed in the same ciliary compartment in each tissue/cell type and whether similar mechanisms and signaling pathways are involved. Standard identifiers should thus be used to illustrate various ciliary components in colocalization studies. Commonly used markers are acetylated $\alpha$-tubulin and RP1 for the distal cilium and more proximal structures, $\gamma$-tubulin for the basal body, Ush2 for the periciliary ridge complex, and rootletin (Crocc) for striated rootlets. Standardizing the data collected for each mutant and in every affected tissue/cell type will allow comparative functional analysis of specific genes. Documenting the histology of the retina with emphasis on the photoreceptor layer is required at distinct stages of degeneration. Electron microscopy in longitudinal sections and cross-sections of the junction between inner and outer segments would be helpful in determining the defects caused by mutations in a specific protein or isoform (see Figure 2). Moreover, a detailed expression pattern with respect to previously defined proteins of specific ciliary compartments will allow more precise localization.

As awareness has grown of the pivotal role of cilia in sensory signaling, various questions persist. Are activated signaling pathways specific for each ciliated tissue or cell type? Do similar multiprotein complexes play similar roles in various tissues? For example, does the composition of BBSome and NPHP-JBTS-MKS complexes [192,193] change in response to microenvironment or required cellular functions in cultured cells versus different tissues? What causes variability in genotype-phenotype correlations? For example, why do only some BBS gene mutations cause both BBS and isolated retinal dystrophy (Figure 1)? Why do only selected NPHP genes additionally cause retinal dystrophy? Do such mutations provide information about which domains of each protein may have tissue-specific functions? CEP290 and RPGR co-localize and both cause LCA/RP. Why then is only CEP290 associated with other syndromic ciliopathies even though RPGR is ubiquitously expressed?

Next-generation sequencing and new proteomics-based approaches are likely to have a major impact on the progress in this field. First, detailed analysis of ciliary localization for each protein in cultured cells and in specific tissues with relevant markers of distinct compartments will refine our understanding of cilia structure and function. Ultrastructural evaluation of photoreceptor basal bodies and connecting cilia and in other ciliated cells in mouse models will provide key information about the role of each protein. With the identification of clusters of interacting proteins $[193,194]$, these interaction networks can be used to define relevant signaling cascades and final common pathways using biochemical and genomic techniques. A better elucidation of ciliary protein networks, their precise functional interactions and downstream signaling events would be relevant for designing therapeutic approaches that are applicable to multiple ciliopathies and pertinent for more than one specific mutation.

\section{Conclusions}

Linking clinical diagnosis and nomenclature of ciliopathies with molecular identification depends on understanding how mutations in individual cilia genes contribute to distinct clinical phenotypes. This remains an important area of investigation. Using CEP290 and RPGR as examples of central proteins in the connecting cilium of the photoreceptor, we discuss the clinical phenotypes of mutations in these genes and in those of their interactors to illustrate this principle. We draw attention to the important conclusion that the cilium is comprised of four distinct compartments, each with discrete localization of proteins. By mapping the known interacting partners for CEP290 and RPGR, we find that hubs and disease networks, such as NPHP, BBS, and others, are concentrated in a single ciliary compartment, yet interact with members of other networks in adjacent compartments. A remaining mystery is to understand the significance of discrete localization of proteins (such as intraflagellar transport proteins) that are known to function across compartments, and the manner in which discrete networks (such as BBS and NPHP) interact with each other. These insights provide clues to the sources of complexity and confusion in the study of ciliopathies. We summarize by suggesting avenues of future pursuit that will clarify and expand the current knowledge in the field.

\section{Abbreviations \\ BB: Basal body; BBS: Bardet-Biedl syndrome; CEP290: Centrosomal protein 290 kDa; Cko: Conditional knockout; COACH: Joubert syndrome with congenital hepatic fibrosis; IFT: Intraflagellar transport; JBTS: Joubert syndrome; LCA: Leber congenital amaurosis; NPHP: Nephronophthisis; RPGR: Retinitis pigmentosa G-protein regulator; SLSN: Senior-Løken syndrome.}

\section{Competing interests}

The authors declare that they have no competing interests.

\section{Authors' contributions}

All authors wrote the paper and designed the figures. All authors read and approved the final version of the manuscript.

\section{Acknowledgements}

The authors thank colleagues in the Neurobiology-Neurodegeneration \& Repair Laboratory for helpful discussions. This research is supported by the intramural research program of the National Eye Institute.

Received: 25 July 2012 Accepted: 19 September 2012

Published: 3 December 2012 


\section{References}

1. Jain R, Pan J, Driscoll JA, Wisner JW, Huang T, Gunsten SP, You Y, Brody SL (2010) Temporal relationship between primary and motile ciliogenesis in airway epithelial cells. Am J Respir Cell Mol Biol 43:731-739

2. Sorokin SP (1968) Reconstructions of centriole formation and ciliogenesis in mammalian lungs. J Cell Sci 3:207-230

3. Berbari NF, O'Connor AK, Haycraft CJ, Yoder BK (2009) The primary cilium as a complex signaling center. Curr Biol 19:R526-R535

4. Taschner M, Bhogaraju S, Lorentzen E (2012) Architecture and function of IFT complex proteins in ciliogenesis. Differentiation 83:S12-S22

5. Wallingford JB, Mitchell $B$ (2011) Strange as it may seem: the many links between Wnt signaling, planar cell polarity, and cilia. Genes Dev 25:201-213

6. Lee JE, Gleeson JG (2011) A systems-biology approach to understanding the ciliopathy disorders. Genome Med 3:59

7. Ishikawa H, Marshall WF (2011) Ciliogenesis: building the cell's antenna. Nat Rev Mol Cell Biol 12:222-234

8. Silverman MA, Leroux MR (2009) Intraflagellar transport and the generation of dynamic, structurally and functionally diverse cilia. Trends Cell Biol 19:306-316

9. Santos N, Reiter JF (2008) Building it up and taking it down: the regulation of vertebrate ciliogenesis. Dev Dyn 237:1972-1981

10. Pedersen $L B$, Rosenbaum $J$ (2008) Intraflagellar transport (IFT) role in ciliary assembly, resorption and signalling. Curr Top Dev Biol 85:23-61

11. Gerdes JM, Katsanis N (2008) Ciliary function and Wnt signal modulation. Curr Top Dev Biol 85:175-195

12. Eggenschwiler JT, Anderson KV (2007) Cilia and developmental signaling Annu Rev Cell Dev Biol 23:345-373

13. Dawe HR, Farr H, Gull K (2007) Centriole/basal body morphogenesis and migration during ciliogenesis in animal cells. J Cell Sci 120(Pt 1):7-15

14. Roy S (2009) The motile cilium in development and disease: emerging new insights. BioEssays 31(7):694-699

15. Hoey DA, Downs ME, Jacobs CR (2012) The mechanics of the primary cilium: an intricate structure with complex function. J Biomech 45:17-26

16. Van der Heiden K, Egorova AD, Poelmann RE, Wentzel JJ, Hierck BP (2011) Role for primary cilia as flow detectors in the cardiovascular system. Int Rev Cell Mol Biol 290:87-119

17. Sattar S, Gleeson JG (2011) The ciliopathies in neuronal development: a clinical approach to investigation of Joubert syndrome and Joubert syndrome-related disorders. Dev Med Child Neurol 53:793-798

18. Louvi A, Grove EA (2011) Cilia in the CNS: the quiet organelle claims center stage. Neuron 69:1046-1060

19. Kartagener M (1933) Zur pathogenese der bronchiektasien: bronchiektasien bei situs viscerum inversus. Beitr Klin Tuberk 83:489-501

20. Vague J, Farnarier G, G S (1950) [Laurence-Moon-Bardet-Biedl syndrome]. Rev Otoneuroophtalmol 22:60-63

21. Joubert M, Eisenring JJ, Andermann F (1968) Familial dysgenesis of the vermis: a syndrome of hyperventilation, abnormal eye movements and retardation. Neurology 18:302-303

22. Eley L, Yates LM, Goodship JA (2005) Cilia and disease. Curr Opin Genet Dev 15:308-314

23. Badano JL, Katsanis N (2006) Life without centrioles: cilia in the spotlight. Cell 125:1228-1230

24. Afzelius BA (1981) Genetical and ultrastructural aspects of the immotile-cilia syndrome. Am J Hum Genet 33:852-864

25. Beales PL, Elcioglu N, Woolf AS, Parker D, Flinter FA (1999) New criteria for improved diagnosis of Bardet-Biedl syndrome: results of a population survey. J Med Genet 36:437-446

26. Waters AM, Beales PL (2003) Bardet-Biedl syndrome. In: Pagon RA, Bird TD, Dolan CR, Stephens K (eds) GeneReviews. University of Washington, Jul 14 [updated 2011 Sep 29]

27. Parisi MA (2009) Clinical and molecular features of Joubert syndrome and related disorders. Am J Med Genet C Semin Med Genet 151C:326-340

28. Otto EA, Tory K, Attanasio M, Zhou W, Chaki M, Paruchuri Y, Wise EL, Wolf MT, Utsch B, Becker C, Nurnberg G, Nurnberg P, Nayir A, Saunier S, Antignac C, Hildebrandt F (2009) Hypomorphic mutations in meckelin (MKS3/ TMEM67) cause nephronophthisis with liver fibrosis (NPHP11). J Med Genet 46:663-670

29. Sun X, Pawlyk B, Xu X, Liu X, Bulgakov OV, Adamian M, Sandberg MA, Khani SC, Tan MH, Smith AJ, Ali RR, Li T (2010) Gene therapy with a promoter targeting both rods and cones rescues retinal degeneration caused by AIPL1 mutations. Gene Ther 17:117-131
30. Chang B, Khanna H, Hawes N, Jimeno D, He S, Lillo C, Parapuram SK, Cheng H, Scott A, Hurd RE, Sayer JA, Otto EA, Attanasio M, O'Toole JF, Jin G, Shou C, Hildebrandt F, Williams DS, Heckenlively JR, Swaroop A (2006) In-frame deletion in a novel centrosomal/ciliary protein CEP290/NPHP6 perturbs its interaction with RPGR and results in early-onset retinal degeneration in the rd16 mouse. Hum Mol Genet 15:1847-1857

31. Rachel RA, May-Simera HL, Veleri S, Gotoh N, Choi BY, Murga-Zamalloa C, McIntyre JC, Marek J, Lopez I, Hackett AN, Brooks M, den Hollander Al, Beales PL, Li T, Jacobson SG, Sood R, Martens JR, Liu P, Friedman TB, Khanna H, Koenekoop RK, Kelley MW, Swaroop A (2012) Combining Cep290 and Mkks ciliopathy alleles in mice rescues sensory defects and restores ciliogenesis. J Clin Investig 122:1233-1245

32. Mockel A, Perdomo Y, Stutzmann F, Letsch J, Marion V, Dollfus H (2011) Retinal dystrophy in Bardet-Biedl syndrome and related syndromic ciliopathies. Prog Retin Eye Res 30:258-274

33. Ramamurthy V, Cayouette M (2009) Development and disease of the photoreceptor cilium. Clin Genet 76:137-145

34. Adams NA, Awadein A, Toma HS (2007) The retinal ciliopathies. Ophthalmic Genet 28:113-125

35. Domire JS, Green JA, Lee KG, Johnson AD, Askwith CC, Mykytyn K (2011) Dopamine receptor 1 localizes to neuronal cilia in a dynamic process that requires the Bardet-Biedl syndrome proteins. Cell Mol Life Sci 68:2951-2960

36. Green JA, Mykytyn K (2010) Neuronal ciliary signaling in homeostasis and disease. Cell Mol Life Sci 67:3287-3297

37. Doherty D (2009) Joubert syndrome: insights into brain development, cilium biology, and complex disease. Semin Pediatr Neurol 16:143-154

38. Whitfield JF (2004) The neuronal primary cilium - an extrasynaptic signaling device. Cell Signal 16:763-767

39. Whitfield JF, Chakravarthy BR (2009) The neuronal primary cilium: driver of neurogenesis and memory formation in the hippocampal dentate gyrus? Cell Signal 21:1351-1355

40. Louie CM, Gleeson JG (2005) Genetic basis of Joubert syndrome and related disorders of cerebellar development. Hum Mol Genet 14:235-242

41. Millen KJ, Gleeson JG (2008) Cerebellar development and disease. Curr Opin Neurobiol 18:12-19

42. Spassky N, Han YG, Aguilar A, Strehl L, Besse L, Laclef C, Ros MR, Garcia-Verdugo JM, Alvarez-Buylla A (2008) Primary cilia are required for cerebellar development and Shh-dependent expansion of progenitor pool. Dev Biol 317:246-259

43. Shiba D, Yokoyama T (2012) The ciliary transitional zone and nephrocystins. Differentiation 83:S91-S96, Epub 2011 Dec 12

44. Winyard P, Jenkins D (2011) Putative roles of cilia in polycystic kidney disease. Biochim Biophys Acta 1812:1256-1262

45. Takiar V, Caplan MJ (2011) Polycystic kidney disease: pathogenesis and potential therapies. Biochim Biophys Acta 1812:1337-1343

46. D'Angelo A, Franco B (2011) The primary cilium in different tissues-lessons from patients and animal models. Pediatr Nephrol 26:655-662

47. Dalagiorgou G, Basdra EK, Papavassiliou AG (2010) Polycystin-1: function as a mechanosensor. Int J BiochemCell Biol 42:1610-1613

48. Hurd TW, Hildebrandt F (2011) Mechanisms of nephronophthisis and related ciliopathies. Nephron Exp Nephrol 118:e9-e14

49. Hildebrandt F, Attanasio M, Otto E (2009) Nephronophthisis: disease mechanisms of a ciliopathy. J Am Soc Nephrol 20:23-35

50. Lancaster MA, Louie CM, Silhavy JL, Sintasath L, Decambre M, Nigam SK, Willert K, Gleeson JG (2009) Impaired Wnt-beta-catenin signaling disrupt adult renal homeostasis and leads to cystic kidney ciliopathy. Nat Med 15:1046-1054

51. Gunay-Aygun M (2009) Liver and kidney disease in ciliopathies. Am J Med Genet C Semin Med Genet 151C:296-306

52. Larusso NF, Masyuk TV (2011) The role of cilia in the regulation of bile flow. Dig Dis 29:6-12

53. Masyuk T, Masyuk A, LaRusso N (2009) Cholangiociliopathies: genetics, molecular mechanisms and potential therapies. Curr Opin Gastroenterol 25:265-271

54. Masyuk Al, Masyuk TV, LaRusso NF (2008) Cholangiocyte primary cilia in liver health and disease. Dev Dyn 237:2007-2012

55. Masyuk Al, Gradilone SA, Banales JM, Huang BQ, Masyuk TV, Lee SO, Splinter PL, Stroope AJ, Larusso NF (2008) Cholangiocyte primary cilia are chemosensory organelles that detect biliary nucleotides via P2Y12 purinergic receptors. Am J Physiol Gastrointest Liver Physiol 295:G725-G734

56. Gradilone SA, Masyuk Al, Splinter PL, Banales JM, Huang BQ, Tietz PS, Masyuk TV, Larusso NF (2007) Cholangiocyte cilia express TRPV4 and detect 
changes in luminal tonicity inducing bicarbonate secretion. Proc Natl Acad Sci U S A 104:19138-19143

57. Masyuk Al, Masyuk TV, Splinter PL, Huang BQ, Stroope AJ, LaRusso NF (2006) Cholangiocyte cilia detect changes in luminal fluid flow and transmit them into intracellular $\mathrm{Ca}^{2+}$ and CAMP signaling. Gastroenterology 131:911-920

58. Bimonte S, De Angelis A, Quagliata L, Giusti F, Tammaro R, Dallai R, Ascenz MG, Diez-Roux G, Franco B (2011) Ofd1 is required in limb bud patterning and endochondral bone development. Dev Biol 349:179-191

59. Marion V, Stutzmann F, Gerard M, De Melo C, Schaefer E, Claussmann A, Helle S, Delague V, Souied E, Barrey C, Verloes A, Stoetzel C, Dollfus H (2012) Exome sequencing identifies mutations in LZTFL1, a BBSome and smoothened trafficking regulator, in a family with Bardet-Biedl syndrome with situs inversus and insertional polydactyly. J Med Genet 49:317-21, Epub 2012 Apr 17

60. Berbari NF, Johnson AD, Lewis JS, Askwith CC, Mykytyn K (2008) Identification of ciliary localization sequences within the third intracellular loop of G protein-coupled receptors. Mol Biol Cell 19:1540-1547

61. Anderson CT, Castillo AB, Brugmann SA, Helms JA, Jacobs CR, Stearns T (2008) Primary cilia: cellular sensors for the skeleton. Anat Rec 291:1074-1078

62. Malone AM, Anderson CT, Stearns T, Jacobs CR (2007) Primary cilia in bone. J MusculoskeletNeuronal Interact 7:301

63. Malone AM, Anderson CT, Tummala P, Kwon RY, Johnston TR, Stearns T, Jacobs CR (2007) Primary cilia mediate mechanosensing in bone cells by a calciumindependent mechanism. Proc Natl Acad Sci U S A 104:13325-13330

64. Haycraft CJ, Zhang Q, Song B, Jackson WS, Detloff PJ, Serra R, Yoder BK (2007) Intraflagellar transport is essential for endochondral bone formation. Development 134:307-316

65. Liu A, Wang B, Niswander LA (2005) Mouse intraflagellar transport proteins regulate both the activator and repressor functions of Gli transcription factors. Development 132:3103-3111

66. Weatherbee SD, Niswander LA, Anderson KV (2009) A mouse model for Meckel syndrome reveals Mks1 is required for ciliogenesis and Hedgehog signaling. Hum Mol Genet 18:4565-4575

67. Cattaneo I, Condorelli L, Terrinoni AR, Antiga L, Sangalli F, Remuzzi A (2011) Shear stress reverses dome formation in confluent renal tubular cells. Cell Physiol Biochem 28:673-682

68. Clement CA, Kristensen SG, Mollgard K, Pazour GJ, Yoder BK, Larsen LA, Christensen ST (2009) The primary cilium coordinates early cardiogenesis and hedgehog signaling in cardiomyocyte differentiation. J Cell Sci 122(Pt 17):3070-3082

69. You Y, Huang T, Richer EJ, Schmidt JE, Zabner J, Borok Z, Brody SL (2004) Role of $\mathrm{f}$-box factor foxj 1 in differentiation of ciliated airway epithelial cells. Am J Physiol Lung Cell Mol Physiol 286:L650-L657

70. Patel AC, Brody SL, Stappenbeck TS, Holtzman MJ (2011) Tracking cell lineage to rediscover (again) the switch from ciliated to mucous cells. Amer J Respir Cell Mol Biol 44:261-263

71. Brody SL, Yan XH, Wuerffel MK, Song SK, Shapiro SD (2000) Ciliogenesis and left-right axis defects in forkhead factor HFH-4-null mice. Am J Respir Cell Mol Biol 23:45-51

72. Horner VL, Caspary T (2011) Disrupted dorsal neural tube BMP signaling in the cilia mutant Arl13b hnn stems from abnormal Shh signaling. Dev Biol 355:43-54

73. Murdoch JN, Copp AJ (2010) The relationship between sonic Hedgehog signaling, cilia, and neural tube defects. Birth Defects Res A Clin Mol Teratol 88:633-652

74. Ross AJ, May-Simera H, Eichers ER, Kai M, Hill J, Jagger DJ, Leitch CC, Chapple JP, Munro PM, Fisher S, Tan PL, Phillips HM, Leroux MR, Henderson DJ, Murdoch JN, Copp AJ, Eliot MM, Lupski JR, Kemp DT, Dollfus H, Tada M, Katsanis N, Forge A, Beales PL (2005) Disruption of Bardet-Biedl syndrome ciliary proteins perturbs planar cell polarity in vertebrates. Nat Genet 37:1135-1140

75. Yang J, Liu X, Zhao Y, Adamian M, Pawlyk B, Sun X, McMillan DR, Liberman MC, Li T (2010) Ablation of whirlin long isoform disrupts the USH2 protein complex and causes vision and hearing loss. PLoS Genet 6:e1000955

76. Peters KR, Palade GE, Schneider BG, Papermaster DS (1983) Fine structure of a periciliary ridge complex of frog retinal rod cells revealed by ultrahigh resolution scanning electron microscopy. J Cell Biol 96:265-276

77. Ghossoub R, Molla-Herman A, Bastin P, Benmerah A (2011) The ciliary pocket: a once-forgotten membrane domain at the base of cilia. Biol Cell 103:131-144

78. Otto EA, Hurd TW, Airik R, Chaki M, Zhou W, Stoetzel C, Patil SB, Levy S, Ghosh AK, Murga-Zamalloa CA, van Reeuwijk J, Letteboer SJ, Sang L, Giles
RH, Liu Q, Coene KL, Estrada-Cuzcano A, Collin RW, McLaughlin HM, Held S, Kasanuki JM, Ramaswami G, Conte J, Lopez I, Washburn J, Macdonald J, Hu J, Yamashita Y, Maher ER, Guay-Woodford LM et al (2010) Candidate exome capture identifies mutation of SDCCAG8 as the cause of a retinal-renal ciliopathy. Nat Genet 42:840-850

79. Omori Y, Chaya T, Katoh K, Kajimura N, Sato S, Muraoka K, Ueno S, Koyasu T, Kondo M, Furukawa T (2010) Negative regulation of ciliary length by ciliary male germ cell-associated kinase (Mak) is required for retinal photoreceptor survival. Proc Natl Acad Sci U S A 107:22671-22676

80. Hong DH, Yue G, Adamian M, Li T (2001) Retinitis pigmentosa GTPase regulator (RPGRr)-interacting protein is stably associated with the photoreceptor ciliary axoneme and anchors RPGR to the connecting cilium. J Biol Chem 276(15):12091-12099

81. Pawlyk BS, Smith AJ, Buch PK, Adamian M, Hong DH, Sandberg MA, Ali RR, Li T (2005) Gene replacement therapy rescues photoreceptor degeneration in a murine model of Leber congenital amaurosis lacking RPGRIP. Invest Ophthalmol Vis Sci 46:3039-3045

82. Zhao Y, Hong DH, Pawlyk B, Yue G, Adamian M, Grynberg M, Godzik A, Li T (2003) The retinitis pigmentosa GTPase regulator (RPGR)-interacting protein: subserving RPGR function and participating in disk morphogenesis. Proc Natl Acad Sci U S A 100:3965-3970

83. Westfall JE, Hoyt C, Liu Q, Hsiao YC, Pierce EA, Page-McCaw PS, Ferland RJ (2010) Retinal degeneration and failure of photoreceptor outer segment formation in mice with targeted deletion of the Joubert syndrome gene, Ahi1. J Neurosci 30:8759-8768

84. Holopainen JM, Cheng CL, Molday LL, Johal G, Coleman J, Dyka F, Hii T, Ahn J, Molday RS (2010) Interaction and localization of the retinitis pigmentosa protein RP2 and NSF in retinal photoreceptor cells. Biochemistry 49:7439-7447

85. Boldt K, Mans DA, Won J, van Reeuwijk J, Vogt A, KinkI N, Letteboer SJ, Hicks WL, Hurd RE, Naggert JK, Texier Y, den Hollander Al, Koenekoop RK, Bennett J, Cremers FP, Gloeckner CJ, Nishina PM, Roepman R, Ueffing M (2011) Disruption of intraflagellar protein transport in photoreceptor cilia causes Leber congenital amaurosis in humans and mice. J Clin Invest 121:2169-2180

86. Chuang JZ, Zhao Y, Sung CH (2007) SARA-regulated vesicular targeting underlies formation of the light-sensing organelle in mammalian rods. Cell 130(3):535-547

87. Kulaga HM, Leitch CC, Eichers ER, Badano JL, Lesemann A, Hoskins BE, Lupski JR, Beales PL, Reed RR, Katsanis N (2004) Loss of BBS proteins causes anosmia in humans and defects in olfactory cilia structure and function in the mouse. Nat Genet 36(9):994-998

88. Sedmak T, Wolfrum U (2010) Intraflagellar transport molecules in ciliary and nonciliary cells of the retina. J Cell Biol 189:171-186

89. Cideciyan AV, Rachel RA, Aleman TS, Swider M, Schwartz SB, Sumaroka A, Roman AJ, Stone EM, Jacobson SG, Swaroop A (2011) Cone photoreceptors are the main targets for gene therapy of NPHP5 (IQCB1) or NPHP6 (CEP290) blindness: generation of an all-cone Nphp6 hypomorph mouse that mimics the human retinal ciliopathy. Hum Mol Genet 20:1411-1423

90. McEwen DP, Koenekoop RK, Khanna H, Jenkins PM, Lopez I, Swaroop A, Martens JR (2007) Hypomorphic CEP290/NPHP6 mutations result in anosmia caused by the selective loss of $\mathrm{G}$ proteins in cilia of olfactory sensory neurons. Proc Natl Acad Sci U S A 104:15917-15922

91. Murga-Zamalloa CA, Ghosh AK, Patil SB, Reed NA, Chan LS, Davuluri S, Peranen J, Hurd TW, Rachel RA, Khanna H (2011) Accumulation of the Raf-1 kinase inhibitory protein (Rkip) is associated with Cep290-mediated photoreceptor degeneration in ciliopathies. J Biol Chem 286:28276-28286

92. Hong DH, Pawlyk B, Sokolov M, Strissel KJ, Yang J, Tulloch B, Wright AF, Arshavsky VY, Li T (2003) RPGR isoforms in photoreceptor connecting cilia and the transitional zone of motile cilia. Invest Ophthalmol Vis Sci 44:2413-2421

93. Brunner S, Skosyrski S, Kirschner-Schwabe R, Knobeloch KP, Neidhardt J, Feil S, Glaus E, Luhmann UF, Ruther K, Berger W (2010) Cone versus rod disease in a mutant Rpgr mouse caused by different genetic backgrounds. Invest Ophthalmol Vis Sci 51:1106-1115

94. Hong DH, Pawlyk BS, Adamian M, Sandberg MA, Li T (2005) A single, abbreviated RPGR-ORF15 variant reconstitutes RPGR function in vivo. Invest Ophthalmol Vis Sci 46:435-441

95. Hong DH, Pawlyk BS, Shang J, Sandberg MA, Berson EL, Li T (2000) A retinitis pigmentosa GTPase regulator (RPGR)-deficient mouse model for X-linked retinitis pigmentosa (RP3). Proc Natl Acad Sci U S A 97:3649-3654

96. Hosch J, Lorenz B, Stieger K (2011) RPGR: role in the photoreceptor cilium, human retinal disease, and gene therapy. Ophthalmic Genet 32:1-11 
97. Kirschner R, Rosenberg T, Schultz-Heienbrok R, Lenzner S, Feil S, Roepman R, Cremers FP, Ropers HH, Berger W (1999) RPGR transcription studies in mouse and human tissues reveal a retina-specific isoform that is disrupted in a patient with X-linked retinitis pigmentosa. Hum Mol Genet 8:1571-1578

98. Mavlyutov TA, Zhao H, Ferreira PA (2002) Species-specific subcellular localization of RPGR and RPGRIP isoforms: implications for the phenotypic variability of congenital retinopathies among species. Hum Mol Genet 11:1899-1907

99. Murga-Zamalloa C, Swaroop A, Khanna H (2010) Multiprotein complexes of Retinitis Pigmentosa GTPase regulator (RPGR), a ciliary protein mutated in X-linked Retinitis Pigmentosa (XLRP). Adv Exp Med Biol 664:105-114

100. Arts HH, Doherty D, van Beersum SE, Parisi MA, Letteboer SJ, Gorden NT, Peters TA, Marker T, Voesenek K, Kartono A, Ozyurek H, Farin FM, Kroes HY, Wolfrum U, Brunner HG, Cremers FP, Glass IA, Knoers NV, Roepman R (2007) Mutations in the gene encoding the basal body protein RPGRIP1L, a nephrocystin-4 interactor, cause Joubert syndrome. Nat Genet 39:882-888

101. Brancati F, Travaglini L, Zablocka D, Boltshauser E, Accorsi P, Montagna G, Silhavy JL, Barrano G, Bertini E, Emma F, Rigoli L, Dallapiccola B, Gleeson JG, Valente EM (2008) RPGRIP1L mutations are mainly associated with the cerebello-renal phenotype of Joubert syndrome-related disorders. Clin Genet 74:164-170

102. Delous M, Baala L, Salomon R, Laclef C, Vierkotten J, Tory K, Golzio C, Lacoste T, Besse L, Ozilou C, Moutkine I, Hellman NE, Anselme I, Silbermann F, Vesque C, Gerhardt C, Rattenberry E, Wolf MT, Gubler MC, Martinovic J, Encha-Razavi F, Boddaert N, Gonzales M, Macher MA, Nivet H, Champion G, Bertheleme JP, Niaudet P, McDonald F, Hildebrandt F et al (2007) The ciliary gene RPGRIP1L is mutated in cerebello-oculo-renal syndrome (Joubert syndrome type B) and Meckel syndrome. Nat Genet 39:875-881

103. Khanna H, Davis EE, Murga-Zamalloa CA, Estrada-Cuzcano A, Lopez I, den Hollander Al, Zonneveld MN, Othman MI, Waseem N, Chakarova CF, Maubaret C, Diaz-Font A, MacDonald I, Muzny DM, Wheeler DA, Morgan M, Lewis LR, Logan CV, Tan PL, Beer MA, Inglehearn CF, Lewis RA, Jacobson SG, Bergmann C, Beales PL, Attie-Bitach T, Johnson CA, Otto EA, Bhattacharya SS, Hildebrandt F et al (2009) A common allele in RPGRIP1L is a modifier of retinal degeneration in ciliopathies. Nat Genet 41:739-745

104. Liu L, Zhang M, Xia Z, Xu P, Chen L, Xu T (2011) Caenorhabditis elegans ciliary protein NPHP-8, the homologue of human RPGRIP1L, is required for ciliogenesis and chemosensation. Biochem Biophys Res Commun 410:626-631

105. Wolf MT, Saunier S, O'Toole JF, Wanner N, Groshong T, Attanasio M, Salomon R, Stallmach T, Sayer JA, Waldherr R, Griebel M, Oh J, Neuhaus TJ, Josefiak U, Antignac C, Otto EA, Hildebrandt F (2007) Mutational analysis of the RPGRIP1L gene in patients with Joubert syndrome and nephronophthisis. Kidney Int 72:1520-1526

106. Pazour GJ, Baker SA, Deane JA, Cole DG, Dickert BL, Rosenbaum JL, Witman GB, Besharse JC (2002) The intraflagellar transport protein, IFT88, is essential for vertebrate photoreceptor assembly and maintenance. J Cell Biol 157:103-113

107. Sukumaran S, Perkins BD (2009) Early defects in photoreceptor outer segment morphogenesis in zebrafish ift57, ift88 and ift172 intraflagellar transport mutants. Vision Res 49:479-489

108. Tsujikawa M, Malicki J (2004) Intraflagellar transport genes are essential for differentiation and survival of vertebrate sensory neurons. Neuron 42:703-716

109. Whitehead JL, Wang SY, Bost-Usinger L, Hoang E, Frazer KA, Burnside B (1999) Photoreceptor localization of the KIF3A and KIF3B subunits of the heterotrimeric microtubule motor kinesin II in vertebrate retina. Exp Eye Res 69:491-503

110. Dafinger C, Liebau MC, Elsayed SM, Hellenbroich Y, Boltshauser E, Korenke GC, Fabretti F, Janecke AR, Ebermann I, Nurnberg G, Nurnberg P, Zentgraf H, Koerber F, Addicks K, Elsobky E, Benzing T, Schermer B, Bolz HJ (2011) Mutations in KIF7 link Joubert syndrome with Sonic Hedgehog signaling and microtubule dynamics. J Clin Invest 121:2662-2667

111. Gerdes JM, Liu Y, Zaghloul NA, Leitch CC, Lawson SS, Kato M, Beachy PA, Beales PL, DeMartino GN, Fisher S, Badano JL, Katsanis N (2007) Disruption of the basal body compromises proteasomal function and perturbs intracellular Wnt response. Nat Genet 39:1350-1360

112. Pretorius PR, Baye LM, Nishimura DY, Searby CC, Bugge K, Yang B, Mullins RF, Stone EM, Sheffield VC, Slusarski DC (2010) Identification and functional analysis of the vision-specific BBS3 (ARL6) long isoform. PLoS Genet 6:e1000884

113. Kim JC, Ou YY, Badano JL, Esmail MA, Leitch CC, Fiedrich E, Beales PL, Archibald JM, Katsanis N, Rattner JB, Leroux MR (2005) MKKS/BBS6, a divergent chaperonin-like protein linked to the obesity disorder BardetBiedl syndrome, is a novel centrosomal component required for cytokinesis. J Cell Sci 118(Pt 5):1007-1020

114. Ansley SJ, Badano JL, Blacque OE, Hill J, Hoskins BE, Leitch CC, Kim JC, Ross AJ, Eichers ER, Teslovich TM, Mah AK, Johnsen RC, Cavender JC, Lewis RA, Leroux MR, Beales PL, Katsanis N (2003) Basal body dysfunction is a likely cause of pleiotropic Bardet-Biedl syndrome. Nature 425:628-633

115. Lim YS, Chua CE, Tang BL (2011) Rabs and other small GTPases in ciliary transport. Biol Cell 103:209-221

116. Liu X, Bulgakov OV, Darrow KN, Pawlyk B, Adamian M, Liberman MC, Li T (2007) Usherin is required for maintenance of retinal photoreceptors and normal development of cochlear hair cells. Proc Natl Acad Sci U S A 104:4413-4418

117. Yang J, Liu X, Yue G, Adamian M, Bulgakov O, Li T (2002) Rootletin, a novel coiled-coil protein, is a structural component of the ciliary rootlet. J Cell Biol 159:431-440

118. Wright RN, Hong DH, Perkins B (2012) RpgrORF15 connects to the Usher protein network through direct interactions with multiple whirlin isoforms. Invest Ophthalmol Vis Sci 53:1519-29, Print 2012 Mar

119. Katsanis N, Ansley SJ, Badano JL, Eichers ER, Lewis RA, Hoskins BE, Scambler PJ, Davidson WS, Beales PL, Lupski JR (2001) Triallelic inheritance in BardetBiedl syndrome, a Mendelian recessive disorder. Science 293:2256-2259

120. Doherty D, Parisi MA, Finn LS, Gunay-Aygun M, Al-Mateen M, Bates D, Clericuzio C, Demir H, Dorschner M, van Essen AJ, Gahl WA, Gentile M, Gorden NT, Hikida A, Knutzen D, Ozyurek H, Phelps I, Rosenthal P, Verloes A, Weigand H, Chance PF, Dobyns WB, Glass IA (2010) Mutations in 3 genes (MKS3, CC2D2A and RPGRIP1L) cause COACH syndrome (Joubert syndrome with congenital hepatic fibrosis). J Med Genet 47:8-21

121. Leitch CC, Zaghloul NA, Davis EE, Stoetzel C, Diaz-Font A, Rix S, Alfadhel M, Lewis RA, Eyaid W, Banin E, Dollfus H, Beales PL, Badano JL, Katsanis N (2008) Hypomorphic mutations in syndromic encephalocele genes are associated with Bardet-Biedl syndrome. Nat Genet 40:443-448

122. Karska-Basta I, Kubicka-Trzaska A, Filemonowicz-Skoczek A, RomanowskaDixon B, Kobylarz J (2008) Alstrom syndrome - a case report and literature review. Klin Oczna 110:188-192

123. Helou J, Otto EA, Attanasio M, Allen SJ, Parisi MA, Glass I, Utsch B, Hashmi S, Fazzi E, Omran H, O'Toole JF, Sayer JA, Hildebrandt F (2007) Mutation analysis of NPHP6/CEP290 in patients with Joubert syndrome and SeniorLoken syndrome. Journal of Medical Genetics 44(10):657-663

124. Roepman R, Letteboer SJ, Arts HH, van Beersum SE, Lu X, Krieger E, Ferreira PA, Cremers FP (2005) Interaction of nephrocystin-4 and RPGRIP1 is disrupted by nephronophthisis or Leber congenital amaurosis-associated mutations. Proc Natl Acad Sci U S A 102:18520-18525

125. Stone EM, Cideciyan AV, Aleman TS, Scheetz TE, Sumaroka A, Ehlinger MA, Schwartz SB, Fishman GA, Traboulsi El, Lam BL, Fulton AB, Mullins RF, Sheffield VC, Jacobson SG (2011) Variations in NPHP5 in patients with nonsyndromic leber congenital amaurosis and Senior-Loken syndrome. Arch Ophthalmol 129:81-87

126. Casteels I, Demandt E, Legius E (2000) Visual loss as the presenting sign of Jeune syndrome. Eur J Paediatr Neurol 4:243-247

127. den Hollander Al, Roepman R, Koenekoop RK, Cremers FP (2008) Leber congenital amaurosis: genes, proteins and disease mechanisms. Prog Retin Eye Res 27:391-419

128. Vervoort R, Lennon A, Bird AC, Tulloch B, Axton R, Miano MG, Meindl A, Meitinger T, Ciccodicola A, Wright AF (2000) Mutational hot spot within a new RPGR exon in X-linked retinitis pigmentosa. Nat Genet 25:462-466

129. Breuer DK, Yashar BM, Filippova E, Hiriyanna S, Lyons RH, Mears AJ, Asaye B, Acar C, Vervoort R, Wright AF, Musarella MA, Wheeler P, MacDonald I, lannaccone A, Birch D, Hoffman DR, Fishman GA, Heckenlively JR, Jacobson SG, Sieving PA, Swaroop A (2002) A comprehensive mutation analysis of RP2 and RPGR in a North American cohort of families with X-linked retinitis pigmentosa. Am J Hum Genet 70:1545-1554

130. Jimeno D, Feiner L, Lillo C, Teofilo K, Goldstein LS, Pierce EA, Williams DS (2006) Analysis of kinesin-2 function in photoreceptor cells using synchronous Cre-loxP knockout of Kif3a with RHO-Cre. Invest Ophthalmol Vis Sci 47:5039-5046

131. Marszalek JR, Liu X, Roberts EA, Chui D, Marth JD, Williams DS, Goldstein LS (2000) Genetic evidence for selective transport of opsin and arrestin by kinesin-II in mammalian photoreceptors. Cell 102:175-187

132. Won J, Shi LY, Hicks W, Wang J, Hurd R, Naggert JK, Chang B, Nishina PM (2011) Mouse model resources for vision research. J Ophthalmol 391384, Epub 2010 Oct 31 
133. Liu Q, Saveliev A, Pierce EA (2009) The severity of retinal degeneration in Rp1h gene-targeted mice is dependent on genetic background. Invest Ophthalmol Vis Sci 50:1566-1574

134. Liu J, Huang Q, Higdon J, Liu W, Xie T, Yamashita T, Cheon K, Cheng C, Zuo J (2005) Distinct gene expression profiles and reduced JNK signaling in retinitis pigmentosa caused by RP1 mutations. Hum Mol Genet 14:2945-2958

135. Gao J, Cheon K, Nusinowitz S, Liu Q, Bei D, Atkins K, Azimi A, Daiger SP, Farber DB, Heckenlively JR, Pierce EA, Sullivan LS, Zuo J (2002) Progressive photoreceptor degeneration, outer segment dysplasia, and rhodopsin mislocalization in mice with targeted disruption of the retinitis pigmentosa1 (Rp1) gene. Proc Natl Acad Sci U S A 99:5698-5703

136. Schwartz SB, Aleman TS, Cideciyan AV, Swaroop A, Jacobson SG, Stone EM (2003) De novo mutation in the RP1 gene (Arg677ter) associated with retinitis pigmentosa. Invest Ophthalmol Vis Sci 44:3593-3597

137. Cideciyan AV, Aleman TS, Jacobson SG, Khanna H, Sumaroka A, Aguirre GK, Schwartz SB, Windsor EA, He S, Chang B, Stone EM, Swaroop A (2007) Centrosomal-ciliary gene CEP290/NPHP6 mutations result in blindness with unexpected sparing of photoreceptors and visual brain: implications for therapy of Leber congenital amaurosis. Hum Mutat 28:1074-1083

138. Louie CM, Caridi G, Lopes VS, Brancati F, Kispert A, Lancaster MA, Schlossman AM, Otto EA, Leitges M, Grone HJ, Lopez I, Gudiseva HV, O'Toole JF, Vallespin E, Ayyagari R, Ayuso C, Cremers FP, den Hollander Al, Koenekoop RK, Dallapiccola B, Ghiggeri GM, Hildebrandt F, Valente EM, Williams DS, Gleeson JG (2010) AHI1 is required for photoreceptor outer segment development and is a modifier for retinal degeneration in nephronophthisis. Nat Genet 42:175-180

139. Lancaster MA, Gopal DJ, Kim J, Saleem SN, Silhavy JL, Louie CM, Thacker BE, Williams Y, Zaki MS, Gleeson JG (2011) Defective Wnt-dependent cerebellar midline fusion in a mouse model of Joubert syndrome. Nat Med 17:726-731

140. Collin GB, Won J, Hicks WL, Cook SA, Nishina PM, Naggert JK (2012) Meckelin is necessary for photoreceptor intraciliary transport and outer segment morphogenesis. Invest Ophthalmol Vis Science 53:967-974, Print 2012 Feb

141. Bhowmick R, Li M, Sun J, Baker SA, Insinna C, Besharse JC (2009) Photoreceptor IFT complexes containing chaperones, guanylyl cyclase 1 and rhodopsin. Traffic 10:648-663

142. Liem KF Jr (2009) He M, Ocbina PJ, Anderson KV: Mouse Kif7/Costal2 is a cilia-associated protein that regulates Sonic hedgehog signaling. Proc Natl Acad Sci U S A 106:13377-13382

143. Chapple JP, Hardcastle AJ, Grayson C, Spackman LA, Willison KR, Cheetham ME (2000) Mutations in the N-terminus of the X-linked retinitis pigmentosa protein RP2 interfere with the normal targeting of the protein to the plasma membrane. Hum Mol Genet 9:1919-1926

144. Evans RJ, Schwarz N, Nagel-Wolfrum K, Wolfrum U, Hardcastle AJ, Cheetham ME (2010) The retinitis pigmentosa protein RP2 links pericentriolar vesicle transport between the Golgi and the primary cilium. Hum Mol Genet 19:1358-1367

145. Hurd T, Zhou W, Jenkins P, Liu CJ, Swaroop A, Khanna H, Martens J, Hildebrandt F, Margolis B (2010) The retinitis pigmentosa protein RP2 interacts with polycystin 2 and regulates cilia-mediated vertebrate development. Hum Mol Genet 19:4330-4344

146. Won J, Gifford E, Smith RS, Yi H, Ferreira PA, Hicks WL, Li T, Naggert JK, Nishina PM (2009) RPGRIP1 is essential for normal rod photoreceptor outer segment elaboration and morphogenesis. Hum Mol Genet 18:4329-4339

147. Pawlyk BS, Bulgakov OV, Liu X, Xu X, Adamian M, Sun X, Khani SC, Berson EL, Sandberg MA, Li T (2010) Replacement gene therapy with a human RPGRIP1 sequence slows photoreceptor degeneration in a murine model of Leber congenital amaurosis. Hum Gene Ther 21:993-1004

148. Garcia-Gonzalo FR, Corbit KC, Sirerol-Piquer MS, Ramaswami G, Otto EA, Noriega TR, Seol AD, Robinson JF, Bennett CL, Josifova DJ, Garcia-Verdugo JM, Katsanis N, Hildebrandt F, Reiter JF (2011) A transition zone complex regulates mammalian ciliogenesis and ciliary membrane composition. Nat Genet 43:776-784

149. Thompson DA, Khan NW, Othman Ml, Chang B, Jia L, Grahek G, Wu Z, Hiriyanna S, Nellissery J, Li T, Khanna H, Colosi P, Swaroop A, Heckenlively JR (2012) Rd9 is a naturally occurring mouse model of a common form of retinitis pigmentosa caused by mutations in RPGR-ORF15. PloS One 7:e35865

150. Huang WC, Wright AF, Roman AJ, Cideciyan AV, Manson FD, Gewaily DY, Schwartz SB, Sadigh S, Limberis MP, Bell P, Wilson JM, Swaroop A, Jacobson SG (2012) RPGR-associated retinal degeneration in human X-linked RP and a murine model. Invest Ophthalmol Vis Sci 53:5594-5608, Print 2012 Sep
151. Jagger D, Collin G, Kelly J, Towers E, Nevill G, Longo-Guess C, Benson J, Halsey K, Dolan D, Marshall J, Naggert J, Forge A (2011) Alstrom syndrome protein ALMS1 localizes to basal bodies of cochlear hair cells and regulates cilium-dependent planar cell polarity. Hum Mol Genet 20:466-481

152. Huang-Doran I, Semple RK (2010) Knockdown of the Alstrom syndromeassociated gene Alms1 in 3 T3-L1 preadipocytes impairs adipogenesis but has no effect on cell-autonomous insulin action. Int J Obesity 34:1554-1558

153. Arsov T, Silva DG, O'Bryan MK, Sainsbury A, Lee NJ, Kennedy C, Manji SS, Nelms K, Liu C, Vinuesa CG, de Kretser DM, Goodnow CC, Petrovsky N (2006) Fat aussie - a new Alstrom syndrome mouse showing a critical role for ALMS1 in obesity, diabetes, and spermatogenesis. Mol Endocrinol 20:1610-1622

154. Collin GB, Cyr E, Bronson R, Marshall JD, Gifford EJ, Hicks W, Murray SA, Zheng QY, Smith RS, Nishina PM, Naggert JK (2005) Alms1-disrupted mice recapitulate human Alstrom syndrome. Hum Mol Genet 14:2323-2333

155. Zhang Q, Nishimura D, Seo S, Vogel T, Morgan DA, Searby C, Bugge K, Stone EM, Rahmouni K, Sheffield VC (2011) Bardet-Biedl syndrome 3 (Bbs3) knockout mouse model reveals common BBS-associated phenotypes and Bbs3 unique phenotypes. Proc Natl Acad Sci U S A 108:20678-20683, Epub 2011 Dec 2

156. Davis RE, Swiderski RE, Rahmouni K, Nishimura DY, Mullins RF, Agassandian K, Philp AR, Searby CC, Andrews MP, Thompson S, Berry CJ, Thedens DR, Yang B, Weiss RM, Cassell MD, Stone EM, Sheffield VC (2007) A knockin mouse model of the Bardet-Biedl syndrome 1 M390R mutation has cilia defects, ventriculomegaly, retinopathy, and obesity. Proc Natl Acad Sci U S A 104:19422-19427

157. Nishimura DY, Fath M, Mullins RF, Searby C, Andrews M, Davis R, Andorf JL, Mykytyn K, Swiderski RE, Yang B, Carmi R, Stone EM, Sheffield VC (2004) Bbs2-null mice have neurosensory deficits, a defect in social dominance, and retinopathy associated with mislocalization of rhodopsin. Proc Natl Acad Sci U S A 101:16588-16593

158. Rahmouni K, Fath MA, Seo S, Thedens DR, Berry CJ, Weiss R, Nishimura DY, Sheffield VC (2008) Leptin resistance contributes to obesity and hypertension in mouse models of Bardet-Biedl syndrome. J Clin Invest 118:1458-1467

159. Abd-El-Barr MM, Sykoudis K, Andrabi S, Eichers ER, Pennesi ME, Tan PL, Wilson JH, Katsanis N, Lupski JR, Wu SM (2007) Impaired photoreceptor protein transport and synaptic transmission in a mouse model of BardetBiedl syndrome. Vis Res 47:3394-3407

160. Mykytyn K, Mullins RF, Andrews M, Chiang AP, Swiderski RE, Yang B, Braun T, Casavant T, Stone EM, Sheffield VC (2004) Bardet-Biedl syndrome type 4 (BBS4)-null mice implicate Bbs4 in flagella formation but not global cilia assembly. Proc Natl Acad Sci U S A 101:8664-8669

161. Simons DL, Boye SL, Hauswirth WW, Wu SM (2011) Gene therapy prevents photoreceptor death and preserves retinal function in a Bardet-Biedl syndrome mouse model. Proc Natl Acad Sci U S A 108:6276-6281

162. Tadenev AL, Kulaga HM, May-Simera HL, Kelley MW, Katsanis N, Reed RR (2011) Loss of Bardet-Biedl syndrome protein-8 (BBS8) perturbs olfactory function, protein localization, and axon targeting. Proc Natl Acad Sci U S A 108:10320-10325

163. Fath MA, Mullins RF, Searby C, Nishimura DY, Wei J, Rahmouni K, Davis RE, Tayeh MK, Andrews M, Yang B, Sigmund CD, Stone EM, Sheffield VC (2005) Mkks-null mice have a phenotype resembling Bardet-Biedl syndrome. Hum Mol Genet 14:1109-1118

164. Sato T, Mushiake S, Kato Y, Sato K, Sato M, Takeda N, Ozono K, Miki K, Kubo Y, Tsuji A, Harada R, Harada A (2007) The Rab8 GTPase regulates apical protein localization in intestinal cells. Nature 448:366-369

165. Kudryashova E, Wu J, Havton LA, Spencer MJ (2009) Deficiency of the E3 ubiquitin ligase TRIM32 in mice leads to a myopathy with a neurogenic component. Hum Mol Genet 18:1353-1367

166. Brancati F, Barrano G, Silhavy JL, Marsh SE, Travaglini L, Bielas SL, Amorini M, Zablocka D, Kayserili H, Al-Gazali L, Bertini E, Boltshauser E, D'Hooghe M, Fazzi E, Fenerci EY, Hennekam RC, Kiss A, Lees MM, Marco E, Phadke SR, Rigoli L, Romano S, Salpietro CD, Sherr EH, Signorini S, Stromme P, Stuart B, Sztriha L, Viskochil DH, Yuksel A et al (2007) CEP290 mutations are frequently identified in the oculo-renal form of Joubert syndrome-related disorders. Am J Hum Genet 81:104-113

167. Valente EM, Silhavy JL, Brancati F, Barrano G, Krishnaswami SR, Castori M, Lancaster MA, Boltshauser E, Boccone L, Al-Gazali L, Fazzi E, Signorini S, Louie CM, Bellacchio E, Bertini E, Dallapiccola B, Gleeson JG (2006) Mutations in CEP290, which encodes a centrosomal protein, cause pleiotropic forms of Joubert syndrome. Nat Genet 38:623-625 
168. Coppieters F, Lefever S, Leroy BP, De Baere E (2010) CEP290, a gene with many faces: mutation overview and presentation of CEP290base. Hum Mutat 31:1097-1108

169. Coppieters F, Casteels I, Meire F, De Jaegere S, Hooghe S, van Regemorter N, Van Esch H, Matuleviciene A, Nunes L, Meersschaut V, Walraedt S, Standaert L, Coucke P, Hoeben H, Kroes HY, Vande Walle J, de Ravel T, Leroy BP, De Baere E (2010) Genetic screening of LCA in Belgium: predominance of CEP290 and identification of potential modifier alleles in AHI1 of CEP290-related phenotypes. Hum Mutat 31:E1709-E1766

170. Morecroft I, Doyle B, Nilsen M, Kolch W, Mair K, Maclean MR (2011) Mice lacking the Raf-1 kinase inhibitor protein exhibit exaggerated hypoxiainduced pulmonary hypertension. Br J Pharmacol 163:948-963

171. lannaccone A, Wang X, Jablonski MM, Kuo SF, Baldi A, Cosgrove D, Morton CC, Swaroop A (2004) Increasing evidence for syndromic phenotypes associated with RPGR mutations. Am J Ophthalmol 137:785-786, author reply 786

172. Shu X, Black GC, Rice JM, Hart-Holden N, Jones A, O'Grady A, Ramsden S, Wright AF (2007) RPGR mutation analysis and disease: an update. Hum Mutat 28:322-328

173. Zito I, Downes SM, Patel RJ, Cheetham ME, Ebenezer ND, Jenkins SA, Bhattacharya SS, Webster AR, Holder GE, Bird AC, Bamiou DE, Hardcastle AJ (2003) RPGR mutation associated with retinitis pigmentosa, impaired hearing, and sinorespiratory infections. J Med Genet 40:609-615

174. Schmid F, Glaus E, Cremers FP, Kloeckener-Gruissem B, Berger W, Neidhardt J (2010) Mutation- and tissue-specific alterations of RPGR transcripts. Invest Ophthalmol Vis Sci 51:1628-1635

175. Hong DH, Li T (2002) Complex expression pattern of RPGR reveals a role for purine-rich exonic splicing enhancers. Invest Ophthalmol Vis Sci 43:3373-3382

176. He S, Parapuram SK, Hurd TW, Behnam B, Margolis B, Swaroop A, Khanna H (2008) Retinitis Pigmentosa GTPase Regulator (RPGR) protein isoforms in mammalian retina: insights into X-linked Retinitis Pigmentosa and associated ciliopathies. Vision Res 48:366-376

177. Meindl A, Dry K, Herrmann K, Manson F, Ciccodicola A, Edgar A, Carvalho MR, Achatz H, Hellebrand H, Lennon A, Migliaccio C, Porter K, Zrenner E, Bird A, Jay M, Lorenz B, Wittwer B, D'Urso M, Meitinger T, Wright A (1996) A gene (RPGR) with homology to the RCC1 guanine nucleotide exchange factor is mutated in X-linked retinitis pigmentosa (RP3). Nat Genet 13:35-42

178. Yan D, Swain PK, Breuer D, Tucker RM, Wu W, Fujita R, Rehemtulla A, Burke D, Swaroop A (1998) Biochemical characterization and subcellular localization of the mouse retinitis pigmentosa GTPase regulator (mRpgr). J Biol Chem 273:19656-19663

179. Iannaccone A, Breuer DK, Wang XF, Kuo SF, Normando EM, Filippova E, Baldi A, Hiriyanna S, MacDonald CB, Baldi F, Cosgrove D, Morton CC, Swaroop A, Jablonski MM (2003) Clinical and immunohistochemical evidence for an $\mathrm{X}$ linked retinitis pigmentosa syndrome with recurrent infections and hearing loss in association with an RPGR mutation. J Med Genet 40:e118

180. Sharon D, Sandberg MA, Rabe WW, Stillberger M, Dryja TP, Berson EL (2003) RP2 and RPGR mutations and clinical correlations in patients with X-linked retinitis pigmentosa. Am J Hum Genet 73:1131-1146

181. Ocbina PJ, Eggenschwiler JT, Moskowitz I, Anderson KV (2011) Complex interactions between genes controlling trafficking in primary cilia. Nat Genet 43:547-553

182. Friedman TB, Schultz JM, Ahmed ZM, Tsilou ET, Brewer CC (2011) Usher syndrome: hearing loss with vision loss. Adv Otorhinolaryngol 70:56-65

183. Murga-Zamalloa CA, Swaroop A, Khanna H (2009) RPGR-containing protein complexes in syndromic and non-syndromic retinal degeneration due to ciliary dysfunction. J Genet 88:399-407

184. Travaglini L, Brancati F, Attie-Bitach T, Audollent S, Bertini E, Kaplan J, Perrault I, lannicelli M, Mancuso B, Rigoli L, Rozet JM, Swistun D, Tolentino J, Dallapiccola B, Gleeson JG, Valente EM, Zankl A, Leventer R, Grattan-Smith P, Janecke A, D'Hooghe M, Sznajer Y, Van Coster R, Demerleir L, Dias K, Moco C, Moreira A, Kim CA, Maegawa G, Petkovic D et al (2009) Expanding CEP290 mutational spectrum in ciliopathies. Am J Med Genet A 149A:2173-2180

185. Chaki M, Hoefele J, Allen SJ, Ramaswami G, Janssen S, Bergmann C, Heckenlively JR, Otto EA, Hildebrandt F (2011) Genotype-phenotype correlation in 440 patients with NPHP-related ciliopathies. Kidney Int 80:1239-1245

186. Zhang Q, Seo S, Bugge K, Stone EM, Sheffield VC (2012) BBS proteins interact genetically with the IFT pathway to influence $\mathrm{SHH}$ related phenotypes. Hum Mol Genet 21:1945-1953, Epub 2012 Jan 6
187. Badano JL, Kim JC, Hoskins BE, Lewis RA, Ansley SJ, Cutler DJ, Castellan C, Beales PL, Leroux MR, Katsanis N (2003) Heterozygous mutations in BBS1, BBS2 and BBS6 have a potential epistatic effect on Bardet-Biedl patients with two mutations at a second BBS locus. Hum Mol Genet 12:1651-1659

188. Beales PL, Badano JL, Ross AJ, Ansley SJ, Hoskins BE, Kirsten B, Mein CA, Froguel P, Scambler PJ, Lewis RA, Lupski JR, Katsanis N (2003) Genetic interaction of BBS1 mutations with alleles at other BBS loci can result in non-Mendelian Bardet-Biedl syndrome. Am J Hum Genet 72:1187-1199

189. Bin J, Madhavan J, Ferrini W, Mok CA, Billingsley G, Heon E (2009) BBS7 and TTC8 (BBS8) mutations play a minor role in the mutational load of BardetBiedl syndrome in a multiethnic population. Hum Mutat 30:E737-E746

190. Katsanis N, Eichers ER, Ansley SJ, Lewis RA, Kayserili H, Hoskins BE, Scambler PJ, Beales PL, Lupski JR (2002) BBS4 is a minor contributor to Bardet-Biedl syndrome and may also participate in triallelic inheritance. Am J Hum Genet 71:22-29

191. Takeda S, Narita K (2011) Structure and function of vertebrate cilia, towards a new taxonomy. Differentiation 83:S4-S11, Epub 2011 Nov 25

192. Nachury MV, Loktev AV, Zhang Q, Westlake CJ, Peranen J, Merdes A, Slusarski DC, Scheller RH, Bazan JF, Sheffield VC, Jackson PK (2007) A core complex of BBS proteins cooperates with the GTPase Rab8 to promote ciliary membrane biogenesis. Cell 129:1201-1213

193. Sang L, Miller JJ, Corbit KC, Giles RH, Brauer MJ, Otto EA, Baye LM, Wen X, Scales SJ, Kwong M, Huntzicker EG, Sfakianos MK, Sandoval W, Bazan JF, Kulkarni P, Garcia-Gonzalo FR, Seol AD, O'Toole JF, Held S, Reutter HM, Lane WS, Rafiq MA, Noor A, Ansar M, Devi AR, Sheffield VC, Slusarski DC, Vincent JB, Doherty DA, Hildebrandt F et al (2011) Mapping the NPHP-JBTS-MKS protein network reveals ciliopathy disease genes and pathways. Cell 145:513-528

194. van Reeuwijk J, Arts HH, Roepman R (2011) Scrutinizing ciliopathies by unraveling ciliary interaction networks. Hum Mol Genet 20(R2):R149-R157

doi:10.1186/2046-2530-1-22

Cite this article as: Rachel et al:: Photoreceptor sensory cilia and ciliopathies: focus on CEP290, RPGR and their interacting proteins. Cilia 2012 1:22.

\section{Submit your next manuscript to BioMed Central and take full advantage of:}

- Convenient online submission

- Thorough peer review

- No space constraints or color figure charges

- Immediate publication on acceptance

- Inclusion in PubMed, CAS, Scopus and Google Scholar

- Research which is freely available for redistribution 